\title{
A review of canine babesiosis: the European perspective
}

\author{
Laia Solano-Gallego ${ }^{1 *}$, Ángel Sainz ${ }^{2}$, Xavier Roura $^{3}$, Agustín Estrada-Peña ${ }^{4}$ and Guadalupe Miró ${ }^{5}$
}

\begin{abstract}
Canine babesiosis is a significant tick-borne disease caused by various species of the protozoan genus Babesia. Although it occurs worldwide, data relating to European infections have now been collected for many years. These data have boosted the publication record and increased our working knowledge of these protozoan parasites. Both the large and small forms of Babesia species (B. canis, B. vogeli, B. gibsoni, and B. microti-like isolates also referred to as "B. vulpes" and "Theileria annae") infect dogs in Europe, and their geographical distribution, transmission, clinical signs, treatment, and prognosis vary widely for each species. The goal of this review is to provide veterinary practitioners with practical guidelines for the diagnosis, treatment and prevention of babesiosis in European dogs. Our hope is that these guidelines will answer the most frequently asked questions posed by veterinary practitioners.
\end{abstract}

Keywords: Babesiosis, Canine, Babesia, Guideline, Consensus

\section{Background}

Towards the end of the 19th Century, Dr. Victor Babes, a Romanian physician, observed microorganisms in the erythrocytes of cattle and sheep with haemoglobinuria. These microorganisms were later named Babesia bovis and Babesia ovis, respectively, with the genus name Babesia after its discoverer [1]. Not long after these observations in ruminants came the first description of Babesia spp. infection in dogs, in Italy (1895) [2]. Currently, these protozoan diseases occur worldwide $[3,4]$.

Parasites of this genus are primarily transmitted through tick bites and as such can infect a wide variety of domestic and wild animals as well as humans [5]. This association arose as a byproduct of the tick's adaptation to feed on blood. Not surprisingly, dogs are one of Babesia spp. many targets, with various species of Babesia infecting canines and causing canine babesiosis (formerly called canine piroplasmosis). Hard ticks are the main vectors for Babesia spp.; within the tick, Babesia spp. undergo the sexual conjugation and the sporogony portions of their life-cycles. These stages occur within the intestinal lumen and then within the haemocoel of the tick. A blood meal will ultimately transmit the sporozoites from the tick's

\footnotetext{
* Correspondence: Laia.Solano@uab.cat

${ }^{1}$ Department of Animal Medicine and Surgery, Faculty of Veterinary

Medicine, Universitat Autònoma de Barcelona, Barcelona, Spain

Full list of author information is available at the end of the article
}

salivary gland to their new vertebrate host, whereupon the protozoan life-cycle is completed by asexual replication (merogony) within the red blood cells, where the parasites appear as merozoites.

This guide to babesiosis in dogs focuses on Europe and is aimed towards informing veterinarians working in small animal practices. This document is intended to answer the most commonly asked questions about the clinical management, including diagnosis, treatment, prognosis and prevention of these parasitic diseases, with an emphasis on the European context.

\section{Review}

Which species of Babesia can infect dogs in Europe?

Traditionally, the morphology of the protozoan (piroplasm merozoites) within the red blood cell was used as the chief taxonomic determinant. This assessment, made by microscopic evaluation of a blood smear, can be used to classify these protozoa as either large (e.g. Babesia canis) or small forms (e.g. Babesia gibsoni). Subsequently, molecular techniques allowed the identification of several species of Babesia that can infect dogs.

The large Babesia spp., previously considered to be $B$. canis, currently include B. canis, Babesia rossi and Babesia vogeli as distinct species [6]. Their identical morphology initially led $B$. rossi and $B$. vogeli to be thought of as subspecies of $B$. canis, although significant differences 
in their clinical presentation, geographical distribution and vector specificity now lead us to consider otherwise [4, 7-10]. In addition, a large-form Babesia species, related to Babesia bigemina, has been described in North Carolina in the United States [11].

Thus far, only three small Babesia species with clinical importance have been described: B. gibsoni, Babesia conradae $[12,13]$, and the recently reported "Babesia vulpes" [14] suggested by Baneth et al. [14] for the previously named Babesia "Spanish dog isolate", Babesia "microti-like", "Babesia (Theileria) annae", and Babesia cf. microti $[15,16]$, based on their natural hosts and on an apparent lack of any pre-erythrocytic stage of infection in lymphocytes. However, no types were fixed for both, "Theileria annae" and "Babesia vulpes"; therefore, these names must be considered nomina nuda and thus unavailable names.

In this review, we will use Babesia microti-like sp. to describe this infection. Interestingly, a Theileria spp. infection phylogenetically closely related to Theileria spp. found in sable has been reported in South Africa as a cause of disease with bleeding tendency associated with severe thrombocytopenia and anaemia in dogs $[17,18]$.

Logically, the geographical distribution of Babesia spp. depends on the presence of competent ticks to transmit each of them; thus far, not all such species have been identified in Europe. For the large Babesia species, only $B$. canis and B. vogeli have been found in Europe; a single record of detection of DNA of $B$. rossi needs confirmation [19]. As far as small Babesia species are concerned, $B$. microti-like sp. and B. gibsoni have been reported in several European countries [4] (Table 1).

In addition, molecular studies reported Theileria equi, Theileria annulata and Babesia caballi infections detected only by polymerase chain reaction (PCR) in dogs from Spain [20], Croatia [21] and France [19]. Theileria equi infections have also been documented in Jordan [22], Nigeria [23] and South Africa [17]. However, the epidemiological and clinical significance of these infections in dogs remain unknown.

\section{What are the vectors and the geographical distributions of Babesia spp. causing disease in dogs in Europe?}

For $B$. canis, the relevant vector is the tick Dermacentor reticulatus. This tick species has a relatively wide range across Europe, preferring cool and wet climates [24]. While particularly abundant in large areas of central Europe, it can be found even in isolated pockets from Portugal to Poland [25]. The association of this tick species with the transmission of $B$. canis has been documented in both field and laboratory studies [26-28], principally those conducted in France and Germany. The adult tick parasitises dogs while immature individuals feed on wild rodents and are endophilous. Adult ticks are most active during the winter months, with increased activity from October to March, if the winter is not too severe. Favourite habitats are the verges of paths that run through open fields or pastures near forests; a preference for sparse, vegetated, and sunny patches explains the tick's affinity for paths [29].

Some experimental data have shown that the brown dog tick, Rhipicephalus sanguineus (s.l.) (hereinafter R. sanguineus), transmits Babesia species (e.g. B. vogeli) that infect dogs [7, 28]. Rhipicephalus sanguineus is abundant in Mediterranean areas, preferring temperate climates, but being endophilous can also tolerate colder regions of central Europe and the British Isles [30]. The importation of tick-infested dogs from Mediterranean regions may be a common feature for cases detected in these colder climes [30]. As yet, there are no complete data for the geographical distribution of the brown dog tick, because unfortunately, no consensus exists regarding its morphological identification [31]. The ability of this tick to survive indoors also complicates any precise determination of its restrictive range in the wild [32]. We do, however, know that hibernation (for example, in the crevices of kennel buildings) is induced as temperatures dip below $6{ }^{\circ} \mathrm{C}$.

Table 1 Geographical distribution, relevant vectors, and the expected size of Babesia spp. in blood smears. Data for the primary Babesia species found in Europe provided

\begin{tabular}{|c|c|c|c|c|}
\hline Species & Geographical distribution & Vector & $\begin{array}{l}\text { Approximate size }(\mu \mathrm{m}) \\
\text { in a blood smear }\end{array}$ & Reference \\
\hline Babesia canis & $\begin{array}{l}\text { Described across most of Europe (from Portugal } \\
\text { to the north and east of Europe), and especially } \\
\text { common in cool and wet climates. Higher } \\
\text { prevalence in central Europe and lower prevalence } \\
\text { in the Mediterranean basin }\end{array}$ & Dermacentor reticulatus & $2.5 \times 4.5$ & $\begin{array}{l}{[9,21,55,56,58,61} \\
84,100,149-151]\end{array}$ \\
\hline Babesia vogeli & $\begin{array}{l}\text { Albania, Croatia, France, Greece, Italy, Portugal, } \\
\text { Romania, Serbia, Slovenia, Spain and Turkey }\end{array}$ & Rhipicephalus sanguineus & $2.5 \times 4.5$ & $\begin{array}{l}{[9,21,55,56,58,61} \\
62,84,100,149-151\end{array}$ \\
\hline Babesia gibsoni & $\begin{array}{l}\text { Croatia, Germany, Italy, Serbia, Slovakia, Spain } \\
\text { and United Kingdom }\end{array}$ & Rhipicephalus sanguineus? ${ }^{a}$ & $1 \times 3$ & {$[21,48,73,152-154]$} \\
\hline $\begin{array}{l}\text { Babesia microti-like } \\
\text { sp. }\end{array}$ & $\begin{array}{l}\text { Croatia, France, Italy, Portugal, Serbia, Spain } \\
\text { and Sweden }\end{array}$ & $\begin{array}{l}\text { Ixodes hexagonus }{ }^{\mathrm{a}} / \mathrm{xodes} \\
\text { canisuga }\end{array}$ & $1 \times 2.5$ & {$[21,35,50,62,63]$} \\
\hline
\end{tabular}

${ }^{a}$ Vectorial ability has not been demonstrated in the laboratory; its role is an assumption based on epidemiological data 
There is also a requirement for some humidity, which can be provided artificially around buildings by ornamental water features and other artificial irrigation. Not surprisingly, mild and humid riverbanks, with their increased density of wild carnivores, are also popular areas of adult tick infestation, which peaks between May and August. The largely unnoticed larvae (hatched from tick eggs) will appear on their hosts in the summer, with the last developmental stage completing in August - September. The hibernating stage is either the engorged nymph or the newly molted adult [32]. Ticks of the complex $R$. sanguineus may serve as potential vectors for B. gibsoni, at least in Europe, while in Asia, its main distribution range is attributed to transmission by the tick Haemaphysalis longicornis [33, 34].

Details of the life-cycle of $B$. microti-like sp. are still largely unknown, but the species Ixodes hexagonus has been implicated as the potential tick vector, given their discovery on dogs infected with the protozoan $[35,36]$. Ixodes hexagonus exclusively develops the "pholeophilic" (burrow-dwelling) cycle, so-called by the French researchers who reported this activity $[37,38]$. Ixodes hexagonus is entirely absent from vegetation, and its free-living stages are confined to the den, where it commonly parasitises hedgehogs and wild carnivores such as foxes. Consequently, this tick favours areas shared with a high density of these wild carnivores and is commonly found on hunting dogs or dogs that investigate burrows, including abandoned ones. Ixodes hexagonus, together with a related species, $I$. canisuga, is present in practically all areas where foxes are abundant [39], including where B. microti-like sp. is yet to be described, which leaves some ambiguity regarding transmission. However, B. microti-like sp. DNA has been identified in both $I$. hexagonus and I. ricinus [40], as well as in I. canisuga [41], although no data exist to substantiate their competence as vectors for $B$. microti-like sp.

An official map displaying the known distribution of D. reticulatus can be found at http://ecdc.europa.eu/en/ healthtopics/vectors/vector-maps/Pages/VBORNET-mapstick-species.aspx. The European distribution of $R$. sanguineus has already been published [32] and updated [42]. The distribution of the other tick species acting as vectors of Babesia spp. to dogs is still too fragmentary to be mapped.

\section{Are there other modes of transmission for these infections in dogs?}

Although protozoans of the genus Babesia undergo part of their life-cycles in the tick vector, the merozoites circulating in the blood may be transmitted to a healthy host directly by blood transfusion. This scenario has been described for B. gibsoni infection [43], which can also be transmitted vertically [44] and by direct contact between dogs through wounds (fighting dogs), saliva or blood ingestion [45-47].
Interestingly, most dogs reported with $B$. gibsoni infection in the United States, Australia, and Europe have been Pit Bull Terriers, a result of their fighting behaviour [45-48]. The first clinical evidence of possible vertical transmission has also been now documented for B. canis [49] and $B$. microti-like sp. [50].

\section{What are the geographical distribution and prevalence of Babesia spp. infections in dogs in Europe?}

The geographical distribution of Babesia spp. infections in Europe is highly variable (Fig. 1) and largely dependent on the distribution of the competent tick vector. In addition, the prevalence of Babesia spp. infections in Europe varies (Table 2), likely because of the various diagnostic techniques used for detection, the country and population analysed, and the species of Babesia under investigation. Table 2 shows the prevalence of Babesia spp. infections in dogs across Europe. Regarding large Babesia species, $B$. canis has been diagnosed in various northern European countries, as well as in central and southern Europe $[4,51]$. Babesia canis is ordinarily considered to be an infection of central Europe, principally because of the abundance of its main vector, $D$. reticulatus, in that region [52]. Results from a questionnaire-based study in France [53] indicated that the annual rate of overall incidence of B. canis infection seen in veterinary clinics was approximately $1 \%$, although some regions reported a higher incidence of up to $16 \%$ [53]. Interestingly, three strains of $B$. canis, based on polymorphisms of the Bc28.1-gene, have been reported in Europe, with a large variation in their geographical distribution [54]. Babesia vogeli has been found in Turkey, Albania, Slovenia, Romania, Italy, France, Spain and Portugal $[4,55,56]$. The prevalence described for B. canis, using molecular methods, ranges from $2.3 \%$ in Italy [57] to $4.6 \%$ in Slovenia [58], $25.3 \%$ in Poland [59], and up to $44.8 \%$ in Romania [60]. With regard to $B$. vogeli, although the number of studies is still low, prevalence is described as ranging from $0.9 \%$ in France [61] to $1.3 \%$ in Slovenia [58].

Concerning the small Babesia species, B. microti-like sp. isolates have been detected in dogs in Croatia [21], Serbia [62], Sweden [63], France [64], and especially in the Iberian Peninsula, specifically northern Portugal [50] and Galicia (Spain) [16, 35, 65]. Babesia microti-like sp. isolates have been detected in red foxes from Spain [66], Portugal [67], Italy [68], Croatia [69], Germany [41], Austria [70], Hungary [71] and Bosnia and Herzegovina [72]. Clinical cases associated with infection by $B$. gibsoni have also been described in Germany [73], Croatia [21], Italy [48], Serbia [51] and Spain [74, 75]. Unfortunately, we still lack detailed geographical distribution and prevalence data for the small-sized Babesia species because most descriptions are based on individual clinical case reports. However, for Croatia, molecular data have revealed a prevalence of $0.7 \%$ 


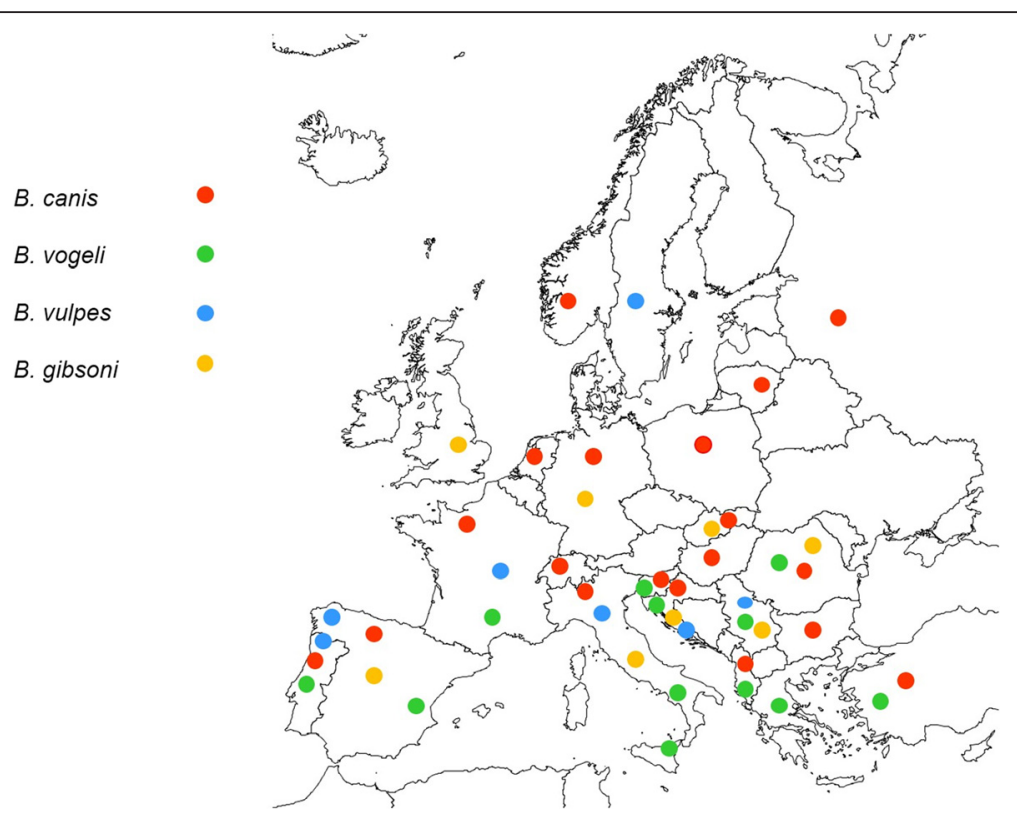

Fig. 1 The distribution of canine Babesia species in Europe in dogs based mainly on molecular analysis. Note the presence of B. canis and B. microti-like sp. mostly in the cooler climate zones of north and central Europe while infection with $B$. vogeli is mainly around the Mediterranean basin. The references for each country are included in the reference list. Figure updated from Solano-Gallego \& Baneth [4]

for B. gibsoni and $0.1 \%$ for B. microti-like sp. [21]. Therefore, epidemiological data of prevalence of clinical illness or subclinical infection is more limited for small Babesia species in Europe.

\section{What is the public health importance of Babesia infections?}

None of the Babesia species that affect dogs and/or cats are considered to be of zoonotic importance [76]. Moreover, there is a lack of evidence that Babesia spp. known to be zoonotic actually have the capacity to infect dogs. However, the data for addressing this topic are incomplete given that some cases of human babesiosis are reported without any firm identification of the causative protozoan species [77].

Human babesiosis is a rare disease and primarily involves just two species of Babesia: Babesia divergens, a parasite of cattle in Europe, and Babesia microti that parasitises small rodents in the United States [76]. Variants of these two zoonotic species in Europe include a $B$. divergens-like species, Babesia sp. EU1 (also called $B$. venatorum) and a $B$. microti-like species, which is only sporadically reported [78].

Infection by $B$. divergens, following transmission by $I$. ricinus, can result in severe clinical disease, especially in immunocompromised patients (undergoing chemotherapy, splenectomised, or human immunodeficiency viruspositive). In immunocompetent individuals, it presents as a mild or subclinical infection [78].

\section{Is there a breed, age or sex predisposition for canine} babesiosis?

A breed predisposition has been suggested in Hungary, citing the vulnerability of the German Shepherd and Komondor breeds to developing babesiosis due to $B$. canis [79]. Predisposition of other breeds for B. canis [80], $B$. vogeli [81], B. gibsoni [45] and B. rossi [82] infections has been described in different latitudes.

Regarding the sex preference, intact females have a lower risk of presenting babesiosis due to $B$. rossi when compared with intact or neutered males and neutered females. The reason for this predisposition has not been fully elucidated [82], but it has been suggested that testosterone causes prolonged and more intense $B$. microti parasitemia in infected male rodents [83].

Young dogs are more likely to present severe babesiosis when infected by $B$. canis, B. vogeli $[4,84]$ or B. rossi [85]. Similarly, old hunting dogs infected by B. microtilike sp. are reported to have a greater risk for developing azotemia [86].

\section{What clinical signs and laboratory abnormalities are found in dogs infected with Babesia spp.?}

The clinical manifestations found during the course of Babesia spp. infections vary, ranging from subclinical infections to multi-organ failure, with a risk of death [87]. While the spectrum of disease may appear daunting, the collection of an extensive history and clinical presentation data backed by laboratory abnormalities should allow the veterinarian to shorten the list of differential 
Table 2 Prevalence of canine infection by Babesia spp. in Europe

\begin{tabular}{|c|c|c|c|c|}
\hline Species & Country & Prevalence in \% (population studied) & Technique employed & Reference \\
\hline \multirow[t]{15}{*}{ Babesia canis } & Slovenia & $4.6(238)$ & PCR & [58] \\
\hline & Spain $^{a}$ & $1.3(153)$ & PCR & [155] \\
\hline & Spain $^{a}$ & 10 (120) & PCR & [35] \\
\hline & Italy ${ }^{a}$ & $20.7(164)$ & PCR & [84] \\
\hline & Italy & $2.3(420)$ & PCR & [57] \\
\hline & Italy ${ }^{b}$ & 70 (249) & IFAT & [156] \\
\hline & Poland ${ }^{b}$ & $25.3(82)$ & PCR & [59] \\
\hline & Croatia & $2.3(848)$ & PCR & [21] \\
\hline & Romania & $44.8(216)$ & PCR & [60] \\
\hline & Romania $^{a}$ & $71.4(49)$ & PCR & [153] \\
\hline & Slovakia ${ }^{c}$ & $3.5(366)$ & PCR & [157] \\
\hline & Lithuania $^{a}$ & $87.8(123)$ & $P C R$ & [158] \\
\hline & Turkey & $0.1(757)$ & PCR & [159] \\
\hline & France & $12.9(140)$ & PCR & [64] \\
\hline & Bulgaria & $16.2(167)$ & ELISA & [160] \\
\hline \multirow[t]{8}{*}{ Babesia vogeli } & Slovenia & $1.3(238)$ & PCR & [58] \\
\hline & Italy ${ }^{a}$ & $6.7(164)$ & PCR & [84] \\
\hline & Italy ${ }^{\mathrm{a}}$ & $4(99)$ & PCR & [93] \\
\hline & Croatia & $0.2(848)$ & PCR & [21] \\
\hline & Serbia & $1.9(158)$ & PCR & [62] \\
\hline & Spain $^{a}$ & $2(153)$ & PCR & [155] \\
\hline & France & $0.9(108)$ & $P C R$ & [61] \\
\hline & France & $13.6(140)$ & PCR & [64] \\
\hline \multirow[t]{5}{*}{ Babesia gibsonid } & Croatia & 0.7 (848) & PCR & [21] \\
\hline & Serbia & $5.7(158)$ & PCR & [62] \\
\hline & Spain $^{a}$ & $2(153)$ & PCR & [155] \\
\hline & Spain $^{a}$ & $2.5(120)$ & $P C R$ & [35] \\
\hline & Romania $^{a}$ & $28.6(49)$ & PCR & [153] \\
\hline \multirow[t]{6}{*}{ Babesia microti-like sp. } & Spain $^{a}$ & $1.9(2,979)$ & Microscopy and PCR & [161] \\
\hline & Spain $^{a}$ & $62.5(120)$ & Microscopy and PCR & [35] \\
\hline & Spain $^{a}$ & $0.7(153)$ & PCR & [155] \\
\hline & Croatia & $0.1(848)$ & $P C R$ & [21] \\
\hline & France & $0.7(140)$ & PCR & [64] \\
\hline & Serbia & $10.1(158)$ & $P C R$ & [62] \\
\hline
\end{tabular}

${ }^{\mathrm{a}}$ Study conducted using dogs with a suspected infection, transmitted by ticks/babesiosis

bStudy conducted using shelter dogs

'Study conducted in Dirofilaria-infected dogs

dPrevalence studies performed in Europe are rare, although clinical cases have been described at various locations

diagnoses [4]. The history and common and diverse clinical signs and laboratory abnormalities observed among the Babesia species, the course of several types of Babesia infection, and prognoses are shown in Table 3.

The wide range of clinical manifestations depends very much on the species of Babesia causing infection and other factors that affect the severity of the disease, including age, splenectomy, immune competence, and concomitant infection or disease $[4,10]$. In addition, disease severity has been associated with parasite density in $B$. rossi infection [88]. However, limited information is available regarding disease severity and parasite density in other Babesia species. In a recent study, parasite density was not different between survivors and non-survivors in dogs infected with $B$. canis [89]. It is likely that different Babesia spp. might result in different parasitemias due to 
Table 3 Primary clinical manifestations and prognosis for dogs infected with the different species of Babesia found in Europe [4]

\begin{tabular}{|c|c|c|c|c|}
\hline & B. canis & B. vogeli & B. gibsoni & B. microti-like sp. \\
\hline $\begin{array}{l}\text { History and } \\
\text { features }\end{array}$ & $\begin{array}{l}\text { Young dogs, adult dogs, hunting } \\
\text { dogs/sheepdogs (German Shepherd } \\
\text { and Komondor) that live outdoors. } \\
\text { A greater number of cases is seen } \\
\text { in autumn, and spring }\end{array}$ & $\begin{array}{l}\text { Puppies or adult/older dogs } \\
\text { with concomitant infectious } \\
\text { or non-infectious diseases }\end{array}$ & $\begin{array}{l}\text { Common in fighting dogs } \\
\text { (Pit Bull Terrier and Tosa) }\end{array}$ & $\begin{array}{l}\text { Young, adult dogs, } \\
\text { guard/hunting dogs } \\
\text { that live outdoors }\end{array}$ \\
\hline Severity of disease & Moderate to severe & Mild to moderate & Moderate to severe & Moderate to severe \\
\hline $\begin{array}{l}\text { Clinical signs } \\
\text { and laboratory } \\
\text { abnormalities that } \\
\text { differ among } \\
\text { Babesia spp. }\end{array}$ & $\begin{array}{l}\text { Petechiae, epistaxis, vomiting, } \\
\text { lymphadenomegaly, hypotension, } \\
\text { low T3 syndrome, mild to moderate } \\
\text { nonregenerative, normochromic, } \\
\text { and normocytic anaemia, regenerative } \\
\text { anaemia (less common), leukopenia } \\
\text { with neutropenia and/or lymphopenia, } \\
\text { hypoalbuminemia, elevation of liver } \\
\text { enzymes (ALT, AST, ALP), hypokalemia, } \\
\text { hyponatremia, and hyperchloremia, } \\
\text { hyperlactatemia, hyperphosphatemia, } \\
\text { hypertriglyceridemia, hypoglycemia, } \\
\text { prerenal and renal azotemia }\end{array}$ & $\begin{array}{l}\text { Regenerative immune- } \\
\text { mediated hemolytic } \\
\text { anaemia, nonregenerative } \\
\text { anaemia, leukocytosis and } \\
\text { leukopenia }\end{array}$ & $\begin{array}{l}\text { Lymph node enlargement, } \\
\text { enlargement of the spleen, } \\
\text { small-bowel diarrhea, weight } \\
\text { loss, protein-losing nephropathy, } \\
\text { PU/PD, and abdominal effusion. } \\
\text { Mild to severe regenerative } \\
\text { immune-mediated hemolytic } \\
\text { anaemia, neutropenia and } \\
\text { leukocytosis. Hypoalbuminemia, } \\
\text { azotemia and elevation of liver } \\
\text { enzymes (ALT, ALP) }\end{array}$ & $\begin{array}{l}\text { Azotemia, proteinuria, } \\
\text { cylindruria and } \\
\text { hyperglobulinemia }\end{array}$ \\
\hline $\begin{array}{l}\text { Course of infection } \\
\text { related to disease } \\
\text { manifestation }\end{array}$ & Acute & Acute and chronic & Acute and chronic & Acute and chronic? \\
\hline Prognosis & Good to poor & Good & Guarded to poor & Guarded to poor \\
\hline Reference & {$[84,89,106,131,162-167]$} & {$[84,106,162]$} & {$[48,102,132,168-171]$} & {$[16,35,86,172]$} \\
\hline
\end{tabular}

Common clinical signs and laboratory abnormalities among Babesia spp.: Fever, lethargy, anorexia, pale mucous membranes, weakness, bounding pulse, jaundice, pigmenturia, mild to severe thrombocytopenia, mild to severe regenerative anaemia due to hemolysis, bilirubinemia, bilirubinuria, and haemoglobinuria

differences in disease severity, but further studies need to confirm this hypothesis.

Differences in virulence have been described among Babesia species infecting dogs. In general, it is assumed that the least pathogenic large-sized species of Babesia is $B$. vogeli, at least for adult dogs, and that the most virulent species is $B$. rossi, which is probably found only in Africa. The pathogenicity of small-sized Babesia spp., such as $B$. gibsoni and B. microti-like sp., is moderate to severe $[4,10,90]$.

There are clinical signs and clinicopathological abnormalities that are common across all Babesia species infecting dogs (Table 3). Frequent clinical signs associated with canine babesiosis are apathy, weakness, anorexia, pale mucous membranes and a poor general condition. All Babesia species can cause fever, enlarged lymph nodes and spleen, anaemia, thrombocytopenia, jaundice and pigmenturia. Although thrombocytopenia, to a varying extent, is frequently detected, the presence of petechiae or ecchymosis is less common. Thrombocytopenia, when present, varies from mild to severe, as does anaemia. Other abnormalities that can be detected include hypoalbuminemia and hyperbilirubinemia $[4,10]$. Depending on the infective species and the course of infection, anaemia can be regenerative; nonregenerative anaemia is more typically associated with $B$. canis [84]. In all species, anaemia is caused by a combination of intravascular and extravascular hemolysis resulting from parasite-caused injury and rupture of red blood cells, the cells' increased osmotic fragility, and the activity of secondary immune-mediated processes.

Some clinical signs and clinicopathological abnormalities differ among Babesia species infecting dogs (Table 3). Many dogs could present other clinical signs that are not directly related to hemolysis by piroplasms but that demonstrate the involvement of other organs. These complications are especially prevalent following infection by $B$. rossi. A non-exhaustive list includes weight loss, acute or chronic nephropathy, glomerulonephritis, coagulation disorders (disseminated intravascular coagulation), jaundice from liver disease, immune-mediated hemolysis or thrombocytopenia, hemoconcentration, shock, metabolic and/or respiratory alkalosis, and/or acidosis, gastrointestinal disorders (vomiting or diarrhea), pancreatitis, ascites, ocular lesions (uveitis or blindness), myalgia, rhabdomyolysis and respiratory problems (edema or acute respiratory distress) [91].

It must be noted that many "carrier" dogs with chronic infections will not present with any clinical signs as the result of premunition or concomitant immunity unless their health deteriorates, for example from immunosuppressive treatment, splenectomy, or any other immune-compromised situation (e.g. post-surgical stress or debilitating disease). This phenomenon has been described in Greyhounds infected by B. vogeli and in Pit Bull Terriers infected by $B$. gibsoni $[45,92]$. It results from the inability of the immune system to eliminate the infection, 
which then establishes itself with more rigour when the immune system is in abatement $[4,10]$.

\section{Is light microscopy evaluation of a blood smear useful for the diagnosis of canine babesiosis?}

Blood smear examination is a useful diagnostic tool for clinical babesiosis in dogs. Microscopy evaluation continues to be the easiest and most accessible diagnostic test for most veterinarians. However, the sensitivity of this method is lower than that of molecular diagnosis in assisting the veterinarian in making a positive diagnosis and is rather dependent on the species infecting the dog. The two forms of Babesia, large (Fig. 2) and small (Figs. 3, 4), can be distinguished using a blood smear. Although light microscopy is highly specific and can be used to diagnose the majority of sick dogs infected by the large forms of Babesia (e.g. B. canis) [4, 84], it is less commonly detected in $B$. vogeli infections [84]. For this infection, more sensitive molecular PCR-based methods, are more appropriate [93]. The small piroplasms (B. gibsoni, B. microti-like sp.) are hard to observe by light microscopy, which has relatively poor to moderate sensitivity [35], and expertise is needed.

Blood smear observation should therefore be a "first step" diagnostic tool, with negative blood smears reassessed by PCR using blood or splenic tissue (Fig. 5). In addition, to identify the species of piroplasm, morphological observation is insufficient, and molecular techniques such as PCR and sequencing are necessary. Fresh blood is always recommended for the smear. Additionally, observation of large Babesia spp. in a capillary blood smear, such as that obtained from the ear or nail, seems to be more easily accomplished thanks to the greater abundance of the parasite in this type of sample $[10,88]$. The limit of detection of parasites in a thin blood smear appear to be parasitemias of $0.5 \%$ [88].

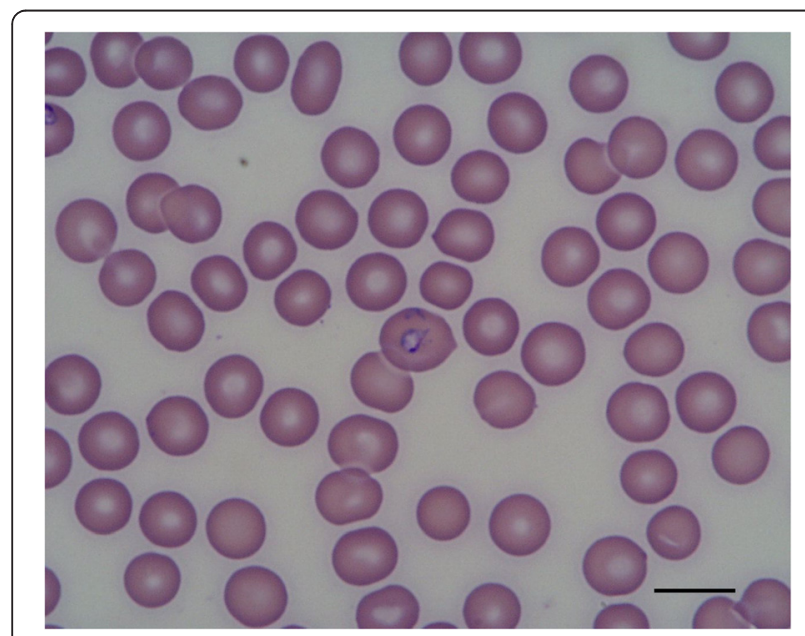

Fig. 2 Photomicrograph showing a large-sized Babesia spp. (B. canis) in canine erythrocytes. Scale-bar: $10 \mu \mathrm{m}$

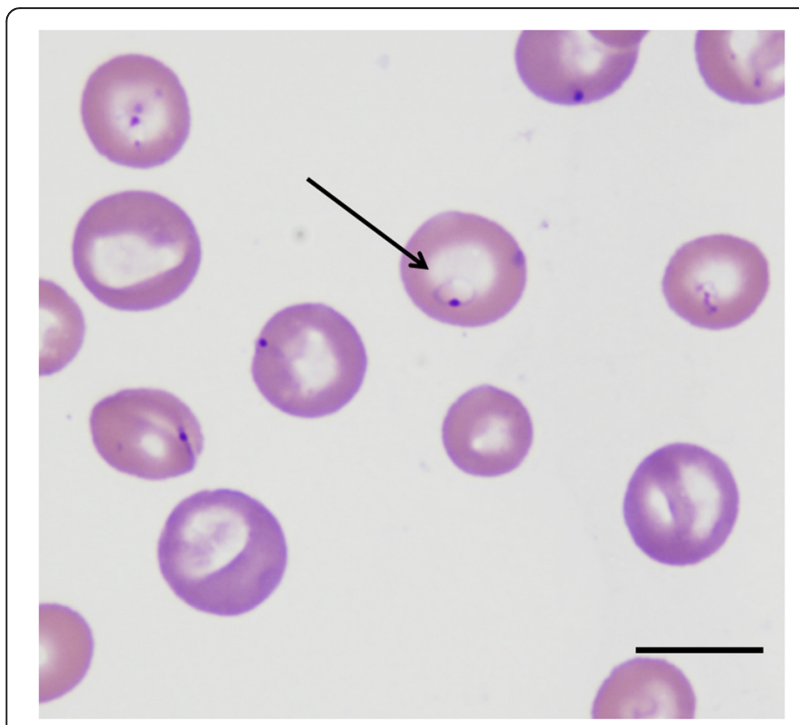

Fig. 3 Photomicrograph of a small-sized Babesia spp. (B. gibsoni, arrow) in canine erythrocytes. Scale-bar: $10 \mu \mathrm{m}$

\section{What serological techniques can be used to diagnose babesiosis?}

The serological tests that can be used are quantitative techniques, such as indirect immunofluorescence (IFAT), or enzyme-linked immunosorbent assay (ELISA). One of the advantages of IFAT or ELISA is that these tests allow us to determine the antibody levels and therefore establish whether they are high or low. For this reason, it is important to send the samples to a laboratory that routinely uses quantitative serological techniques and can provide a final titre by IFAT or optical density by ELISA [42]. Rapid techniques are not yet commercially available for the detection of anti-Babesia antibodies for the clinical setting and will offer only a "positive/negative" result, without providing an antibody titre or level. Furthermore, quantitative techniques

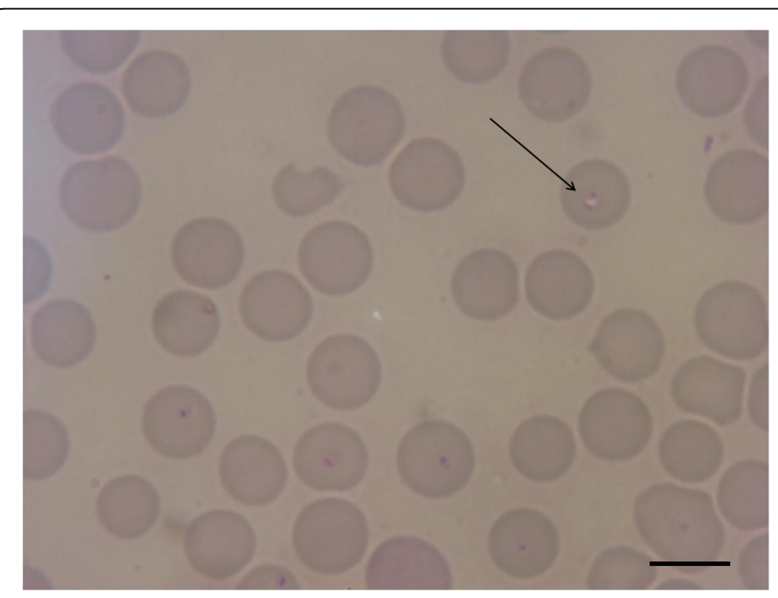

Fig. 4 Photomicrograph of a small Babesia (B. microti-like sp., arrow) in canine erythrocytes. Scale-bar: $10 \mu \mathrm{m}$ 


\section{DOGS WITH CLINICAL SIGNS AND CLINICOPATHOLOGICAL ABNORMALITIES COMPATIBLE WITH BABESIOSIS}
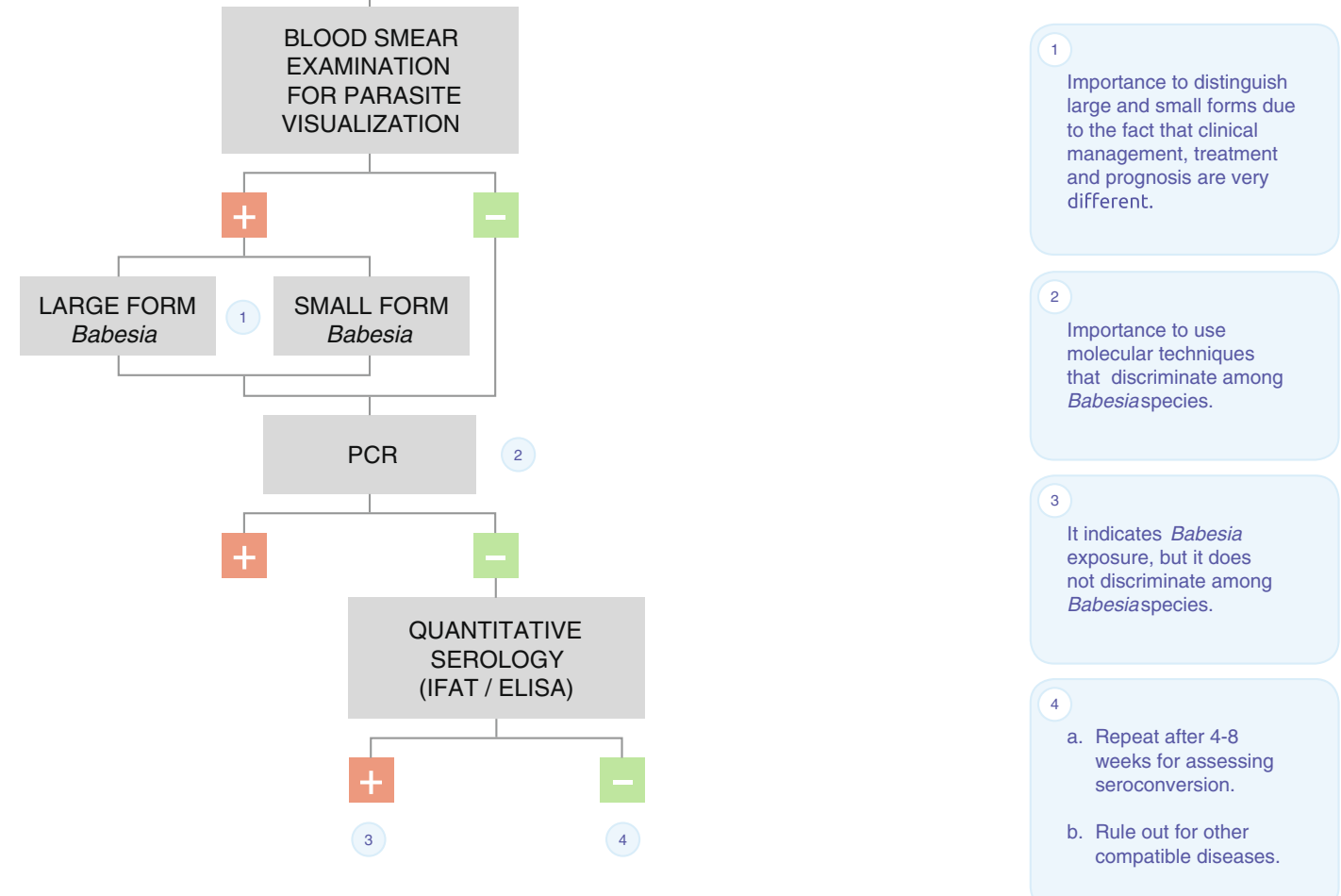

Fig. 5 Diagnostic algorithm for canine babesiosis

are generally more sensitive and specific than rapid techniques. Currently, no universal antigen has been developed for screening using routine diagnostic serology against all Babesia species that infect dogs. The most commonly used antigen in practice and research is that for B. canis; B. gibsoni $[94,95]$ and $B$. microti-like sp. [35] antigens are also available, but information is scarce regarding these antigens. In addition, the specificity and sensitivity of these techniques are not well established [4]. Therefore, the scope for diagnosis by serology is extremely limited and requires further investigation. Nevertheless, false-negative PCR results have been reported in chronic babesiosis involving $B$. gibsoni, attributed to parasite elimination from the circulating blood by the host. These data show that in the long term (up to 420 days post-infection), an infection might be revealed by serology only retrospectively [95].

How should we interpret a positive serological result for Babesia spp.? Do serological cross-reactions exist among different species of Babesia?

The interpretation of a positive result for Babesia when using a serological technique is complicated by crossreactivity among the different species. In general terms, there is significant cross-reactivity between different species of Babesia, especially the more phylogenetically related species. For example, cross-reactivity for large Babesia spp. (B. canis and B. vogeli) can result in matching antibody levels across species. Cross-reactions can also exist between small Babesia spp. (B. gibsoni) and large species (B. canis) [96] as well as between small Babesia spp. (B. gibsoni and B. microti-like sp.) or between large Babesia spp. (B. canis, B. vogeli and B. rossi) [28].

For this reason, a positive result would indicate exposure to infection by Babesia but not precisely identify which species. A positive serological result can also indicate a past or current infection. Despite their infrequent use in the clinical setting, molecular techniques would provide a more informative diagnosis.

\section{Could a seronegative dog be infected with Babesia spp.?}

It is perfectly feasible for a dog to be seronegative and infected with Babesia because infections by species such as $B$. canis manifest acutely $[4,97]$. Consequently, the three to four-week lag in post-infection antibody production would provide a serologically negative window. Therefore, seroconversion could be used as a serological technique to confirm acute infection by Babesia spp. In these cases, initial quantitative serology should be performed when the 
patient first presents with clinical signs and/or laboratory abnormalities. Subsequently, quantitative serology should be performed again after 4-8 weeks (see Fig. 5). Medium to high positive antibody levels during the convalescent phase (at least 3-4 weeks after infection) can confirm infection by Babesia at the time of presentation [35]. However, data are limited about the usefulness of seroconversion in canine Babesia infections. Seroconversion is not commonly employed in clinical practice.

\section{Why is the amplification of DNA by PCR useful in the diagnosis of babesiosis? What biological samples should be chosen to perform a molecular diagnosis of Babesia spp. infections?}

In general terms, PCR is very useful in diagnosing babesiosis. First, PCR detection is more sensitive than a direct blood smear examination. Secondly, the detection of DNA for a specific pathogen in a clinical setting can be considered evidence of an active - and therefore ongoing infection. In addition, unlike direct detection by light microscopy or serology, PCR allows a more reliable identification of the causative species infecting the dog [4].

Different molecular techniques allow the identification and differentiation of the various species of Babesia. These include semi-nested PCR [98], reverse line blotting $[99,100]$, and PCR-restriction fragment length polymorphism analysis [101]. In addition, several genes are commonly used to discriminate among Babesia species. Typically, these include the nuclear ribosomal RNA genes $[7,8]$ and the two internal transcribed spacers (ITS1 and ITS2) [7]. These molecular techniques allow us to refine our diagnosis to the species level and thus provide a more accurate prognosis. Finally, PCR DNA amplification can be a useful technique for monitoring treatment [102].

Ideally, peripheral blood buffered with ethylenediaminetetraacetic acid (EDTA) should be used to conduct molecular analyses using PCR. Moreover, splenic tissue can also be useful, although, as mentioned below, this sample is not usually pursued because it involves a more invasive procedure [4].

\section{Are co-infections common in dogs infected with Babesia spp.? What is the clinical importance of a co-infection for the progression of disease?}

Co-infections with Babesia spp. are not well documented and are rarely reported in dogs. However, sequencing and phylogenetic analyses suggest that the diversity of piroplasm species that co-infect dogs may be greater than previously thought $[15,21]$. A study conducted with 120 Spanish dogs from Galicia and Asturias, all with clinical signs compatible with babesiosis, demonstrated the presence of B. microti-like sp. in 75 dogs (62.5\%), with 15 dogs positive for other piroplasmid species (12 for B. canis and three for B. gibsoni) [35]. Co-infection with other agents was not detected, possibly indicating that coinfection with other pathogens is not common [35]. Moreover, an interesting study found a high percentage of co-infection with different strains of $B$. canis in dogs from France [39]. In addition, co-infection with $B$. rossi and $B$. vogeli and a triple infection with $B$. rossi, B. vogeli and Ehrlichia canis have been reported in South African dogs [103]. In contrast to the rare occurrence of co-infection with different species of Babesia, it could be common in endemic areas to find dogs co-infected with other pathogens such as Leishmania spp., Ehrlichia/Anaplasma spp., Hepatozoon spp. or Rickettsia conorii, depending on the geographical area and the distribution of the competent arthropod vectors [93, 104]. Additionally, it should be noted that co-infection is of major clinical importance for several reasons: it complicates diagnoses, exacerbates clinical signs, reduces effectiveness of treatment, and can worsen the prognosis [104].

\section{What is the treatment of choice for Babesia infections?}

Despite the large number of clinical cases and uncontrolled experimental studies, little robust scientific evidence is available regarding the treatment of canine babesiosis; Table 4 displays those currently used in dogs. Imidocarb dipropionate is the treatment of choice for canine babesiosis caused by the large Babesia species. One dose of $6.6 \mathrm{mg} / \mathrm{kg}$ intramuscularly (IM) or subcutaneously (SC) is the recommended treatment. Although some authors suggest an additional dose of imidocarb (separated by 15 days for $B$. canis and B. vogeli infections), if the dog does not respond adequately, it may be wiser to reconsider the diagnosis. Moreover, this approach is not the treatment of choice for small Babesia species (B. gibsoni and B. microti-like sp.). The most frequently described side effects associated with this drug are pain at the injection site and cholinergic signs (anorexia, hypersalivation, epiphora, abdominal pain, vomiting and diarrhea), which generally disappear quite quickly, although these latter effects can be ameliorated by pre-medicating with atropine or glycopyrrolate [12, 16, 105-107]. The toxic effect of an overdose of imidocarb dipriopionate is nephrotoxicity.

The combination of atovaquone and azithromycin is the only treatment that has been proven to reduce parasitemia with B. gibsoni below the PCR limit of detection. Atovaquone is an anti-parasitic drug that inhibits the action of cytochrome $b$. The most commonly used dose of atovaquone is $13.5 \mathrm{mg} / \mathrm{kg}$, administered per os (PO) every $8 \mathrm{~h}$ with fatty food (to maximise drug absorption) and in combination with azithromycin (at a dose of $10 \mathrm{mg} / \mathrm{kg} \mathrm{PO}$ ) for ten days. This drug combination also seems to be effective in treating infections with other small Babesia species like B. conradae [108] 
Table 4 Treatments used for infections with the various species of Babesia

\begin{tabular}{|c|c|c|c|c|}
\hline Species & Drugs & Efficacy & Dosage & References \\
\hline \multirow{2}{*}{$\begin{array}{l}\text { Babesia canis; } \\
\text { Babesia vogeli }\end{array}$} & Imidocarb dipropionate & Good & 6.6 mg/kg IM/SC once (can be repeated after 15 days) & {$[105,106]$} \\
\hline & Doxycycline & Poor & 10 mg/kg/day PO, 30 days & [117] \\
\hline \multirow[t]{3}{*}{ Babesia microti-like sp. } & Imidocarb dipropionate & Poor & 6.6 mg/kg IM/SC once (can be repeated after 15 days) & {$[12,16,105,106$} \\
\hline & Azithromycin + Atovaquone & Good to moderate & $10 \mathrm{mg} / \mathrm{kg}$ PO SID/10 d + $13.5 \mathrm{mg} / \mathrm{kg}$ PO TID/10 days & {$[109,113]$} \\
\hline & Azithromycin + Buparvaquone & Good to moderate & 10 mg/kg PO SID +5 mg/kg IM (repeat after 48 h) & [113] \\
\hline
\end{tabular}

and is likely to be useful in treating B. microti-like sp. infections. Nonetheless, it seems that in some cases, a lower rate of success with atovaquone treatment is being reported [102, 108-112]. Recently, the use of two IM doses of buparvaquone at $5 \mathrm{mg} / \mathrm{kg}$ separated by $48 \mathrm{~h}$ has demonstrated good clinical efficacy in dogs naturally infected by B. microti-like sp. in Spain, with results superior to those achieved with atovaquone [113].

Diminazene also seems effective against $B$. canis when administered IM as a single dose of $3.5 \mathrm{mg} / \mathrm{kg}$. However, it does not have the same efficacy against B. gibsoni, although it does reduce parasitemia, morbidity and mortality. Side effects include neurological abnormalities, which can be severe on overdose. Its use is currently restricted to clinical cases that are refractory to other treatments $[114,115]$, and it is not commonly used in Europe. The use of combined clindamycin, diminazene and imidocarb dipropionate may also be promising in the treatment of B. gibsoni, as compared to the combination of atovaquone and azithromycin [116].

Antibiotics are not the treatment of choice for piroplasmosis. Nonetheless, doxycycline has been described as lessening the severity of clinical signs and is associated with a reduction in morbidity and mortality for $B$. canis and B. gibsoni infections [117, 118]. The most commonly used dose is $10 \mathrm{mg} / \mathrm{kg} /$ day, administered PO or (sporadically) intravenous (IV). In case of vomiting, the recommendation is to split the dose into $5 \mathrm{mg} / \mathrm{kg}$ given every $12 \mathrm{~h}$ [117]. Clindamycin has been used in the treatment of B. gibsoni infection at a dose of $25 \mathrm{mg} /$ $\mathrm{kg}$, administered PO every $12 \mathrm{~h}$ for 14 days and has been shown to reduce clinical signs and laboratory abnormalities [119]. It is important to remember that antibiotics alone will not eliminate the infection. However, combinations of different antibiotics have some efficacy in treating dogs infected with B. gibsoni. Examples include the combination of clindamycin $(11 \mathrm{mg} / \mathrm{kg}$ every $12 \mathrm{~h}$ PO), metronidazole (15 mg/kg every $12 \mathrm{~h} \mathrm{PO}$ ), and doxycycline $(5 \mathrm{mg} / \mathrm{kg}$ every $12 \mathrm{~h} \mathrm{PO}$ ); or enrofloxacin $(2.5 \mathrm{mg} / \mathrm{kg}$ every $12 \mathrm{~h} \mathrm{PO})$, metronidazole $(5-15 \mathrm{mg} / \mathrm{kg}$ every $12 \mathrm{~h} \mathrm{PO})$, and doxycycline (7-10 mg/kg every $12 \mathrm{~h}$ PO) $[118,120]$. In summary, because of the scarce scientific evidence regarding the efficacy of antibiotics in treating canine babesiosis, their use in these diseases should be restricted.
Other treatments used with varying success to treat babesiosis in dogs include quinuronium sulfate, trypan blue solution and pentamidine; experimental treatments include artesunate, plant extracts or tick peptides [114, 121-125].

\section{Are there other supportive therapies that could be used for babesiosis?}

Supportive treatment is provided only to dogs admitted for inpatient hospital-based care. Supportive care is required for moderate to severe babesiosis. It is difficult to characterise the proportion of cases that need supportive treatment, which varies depending on the type of Babesia species infecting the dog.

In dehydrated or hypovolemic dogs, the use of intravenous crystalloid fluid therapy is indicated, together with the correction of electrolyte and acid-base abnormalities. Fluid therapy is also essential for maintenance of blood volume and adequate end-organ perfusion, diuresis and prevention of red blood cell sludging in capillaries $[10,126]$. In dogs with clinical signs associated with anaemia, packed red blood cell transfusions should be provided using pre-screened units; alternatively, synthetic haemoglobin can be used. Dogs with disseminated intravascular coagulation or coagulation disorders may require plasma transfusions.

The use of immunosuppressant drugs in dogs with immune-mediated haemolytic anaemia (IMHA) or thrombocytopenia is controversial because these conditions are always associated with infectious disease. If the dog is stable and does not require hospitalisation, treatment should be restricted to antiprotozoal agents; treatment should not be initiated exclusively in relation to the hematocrit or platelet value but rather based on the clinical signs associated with the anaemia or thrombocytopenia. Thus, occasionally, dogs with a hematocrit or platelet value of less than $15 \%$ or $40,000 / \mu l$, respectively, may manifest good progress when treated with anti-babesial therapy alone. If, despite antiprotozoal treatment, the dog has moderate-to-severe clinical signs (or a high risk for them), such as sudden collapse or spontaneous bleeding associated with IMHA (e.g. severe spherocytosis, autoagglutination, anti-erythrocyte antibodies or positive Coomb's or antinuclear antibody tests) and/or immune-mediated thrombocytopenia (when platelets/ $\mu$ lare between 20,000 and 40,000), the use of $2 \mathrm{mg} / \mathrm{kg} /$ day of prednisone is 
recommended because prognosis is guarded to poor with reported mortality rates of $28-70 \%$ [127, 128]. However, because no laboratory test or hematological parameter allows the clinician to decide if the immunosuppressant treatment is really necessary, in the majority of such cases, a short course of treatment (ten days or less) is sufficient for secondary IMHA or thrombocytopenia. Moreover, a dose reduction could be implemented more rapidly than usual when there are primary immune-mediated alterations. Other immunosuppressant drugs have not shown the same efficacy and are therefore not recommended. Dogs previously treated with immunosuppressant drugs over a sustained period of time before their treatment for babesiosis do not have as good a clinical response and may be predisposed to other infections and/or relapses $[4,10$, 126]. Pulmonary thromboembolism is a common cause of death in dogs with IMHA. Therefore, heparin, acetylsalicylic acid or clopridogrel might be used as a thromboprophylaxis in dogs with IMHA [129].

Many other supportive therapies may be beneficial depending on the clinical signs and/or laboratory abnormalities, both those caused by the babesiosis directly and those resulting from its treatment with antiprotozoal agents. For example, anti-emetics should be used to counter vomiting, or oxygen therapy should be used when there is respiratory distress $[126,130]$.

\section{What is the expected clinical response following the treatment of babesiosis?}

The majority of dogs infected with large piroplasms (B. canis and B. vogeli) improve clinically in days 1-7 after specific antiprotozoal treatment, although some dogs will not respond until more than 15 days have passed. Dogs infected with B. canis or B. vogeli will generally manifest a complete recovery following their treatment $[90,131]$. In general, the clinical response is good and more rapid (24-48 h) in dogs infected with the large Babesia species than with small $[4,10]$. However, a recent study reported a high mortality rate (53\%, 8 out of 15 ) in dogs with babesiosis due to $B$. canis during the first $24-48 \mathrm{~h}$ after clinical presentation and treatment [89]. In canine B. canis infections, poor outcome and mortality are associated with moderate anaemia, severe thrombocytopenia, mild to moderate leukopenia, hyperlactatemia, moderately increased serum phosphate and triglyceride concentrations and moderately decreased total serum protein concentrations [89].

Some dogs infected with $B$. gibsoni and treated with atovaquone and azithromycin do not show relapse of the disease, and some remain PCR-negative for several years. However, dogs that remain infected with B. gibsoni following treatment may present with a different clinical picture. They may demonstrate a complete resolution of anaemia, without clinical recurrence after stress (including unrelated, disease-mediated), although occasionally, mild thrombocytopenia or hypergammaglobulinemia persists. For some dogs, clinical signs may disappear entirely, but moderate anaemia, thrombocytopenia or hypergammaglobulinemia will persist. Finally, in some other dogs, the clinicopathological abnormalities may be resolved but can reappear under stressful circumstances, which is especially common in splenectomised dogs [102, 132].

In general, little information is available regarding the clinical response of dogs infected with $B$. microti-like sp. isolates. We would predict that their clinical progression would be similar to that described for dogs infected with B. gibsoni, likely because of the lack of any truly effective treatment [16]. However, azotemia has been reported to be the main cause of death for B. microti-like sp.-infected dogs, with a mortality rate of $22 \%$ [86], although a pre-renal azotemia was not fully ruled out. Furthermore, a recent study carried out in the same area did not yield the same findings [35]. In general, these dogs have a very poor response to protocols using imidocarb dipropionate [113]. Other therapeutic alternatives are being considered, such as combinations of atovaquone or buparvaquone with azithromycin. In the majority of dogs treated with these combinations, the trend is towards a favourable initial clinical response [113], but further follow-up studies are needed to evaluate and compare relapse intervals for the various protocols. Therefore, follow-up blood tests (complete blood count and biochemical profile) are needed until hematocrit, platelet concentration, and liver/kidney abnormalities normalise. This is especially important in splenectomised dogs or those dogs infected with $B$. gibsoni or B. microti-like sp.

\section{How do antibody levels evolve following treatment?}

In general, antibody levels to Babesia spp. start decreasing three weeks after initiating treatment and decrease gradually thereafter over approximately 160 days [133]. Antibody results should always be interpreted with caution because elevated antibody levels have been reported to routinely correlate with persistent infection [134]. For some species of Babesia (e.g. B. gibsoni), it is normal to find positive antibody levels following treatment, which complicates the interpretation of positive results [111]. Taken together, these limitations, along with those already described for serological analyses, make it inadvisable to employ these techniques in disease follow-up.

\section{Why is PCR useful after treatment?}

PCR is a useful screening strategy given that many dogs remain chronically infected with piroplasms. Their chronically infected status predisposes these dogs to relapse or to the maintenance of a chronically abnormal - and therefore injurious - clinical state. Under these circumstances, 
PCR can be used to establish whether the infection remains or has been most likely cleared $[4,10]$.

PCR should be performed before interrupting treatment and approximately 2 months after the completion of treatment, especially when monitoring small Babesia species. Additionally, because the sensitivity of PCR for piroplasms in whole blood is less than $100 \%$, it may be advisable to perform two consecutive PCR tests, separated by at least 15 days [102, 111]. In addition, true parasitic clearance can be rigorously demonstrated only if PCR is performed using multiple tissue aspirates, such as from the spleen, not just peripheral blood [10]. The prohibitive cost of several splenic PCR tests tends to restrict its use to the research setting and to proof-ofprinciple studies for therapeutic response.

\section{Can canine babesiosis be cured?}

Clinical cure and a good therapeutic response are much more likely achieved for infections by large-sized Babesia species than infections by the small-sized species, the latter of which tend to be more refractory to conventional treatments [4]. Several therapeutic protocols aimed at infections caused by small Babesia species are used, although parasitological cures are considered rare. The persistence of B. gibsoni in dogs following treatment with different protocols using clindamycin, metronidazole, doxycycline, diminazene, imidocarb dipropionate, atovaquone, and azithromycin is testament to the resilience of this parasite $[111,112,116,119]$.

\section{Can dogs be re-infected by Babesia spp.?}

The same dog can be re-infected by identical Babesia species or co-incidentally with a second species. Although the clinical consequences of re-infections are not well defined, in endemic regions, it is possible for dogs to be chronically infected, in a premunition phase, without clinical consequences; this phase may even be beneficial in terms of protecting against future infection [133].

\section{What tick control measures can be implemented to prevent infection by Babesia spp. in dogs?}

The predominant emphasis for the prevention of babesiosis in dogs has been to focus on tick control. However, this approach is complicated by the endophilic nature of at least some of the ticks involved in its transmission. The efficient transovarial transmission of Babesia species in the tick implies that tick populations in endemic areas can remain infected for a long time and that dogs in contact with tick-infested areas will routinely become re-infested and exponentially amplify the tick population.

Tick prophylaxis should cover the entire period during which ticks are active, depending on the level of risk and lifestyle of the dogs. This prophylaxis may consist of regular checking of the pet for ticks by the owner and veterinarians and the regular use of acaricidal treatment.

Actions for the prevention of transmission of Babesia infections should focus first and foremost on the following:

1. Any attached tick should be removed. Pet owners should be aware of the importance of removing ticks as soon as possible. A large variety of purpose-designed tick removal tools are available (these may be used for removal of ticks attached to the skin; oil, alcohol or ether are not recommended).

2. Dogs and cats travelling to regions with ticks and endemic for babesiosis should also receive a regular acaricidal treatment, particularly if this disease is not endemic in their area.

3. Use acaricides with a residual action and water resistance.

4. Engaging in tick control, applying a good knowledge of tick seasonality. Ticks may be active and parasitise dogs above an ambient average air temperature of $12{ }^{\circ} \mathrm{C}$. Below this temperature, it becomes difficult for dogs to become infested, which makes tick control much easier. Although tick control is classically recommended between spring and autumn, recent studies suggest that in some areas, it should be applied all year around $[135,136]$; however, this recommendation should be considered according to local conditions.

5. The removal of ticks from kennels is unfeasible; therefore, the only and safe way to avoid the colonisation of kennels and premises by ticks is the protection of dogs, which are the only "carriers" of ticks.

Principle active compounds considered to be effective for the treatment and prevention of tick infestations in dogs include a wide variety of ectoparasiticides, which have shown different effects on ticks (repellency, antifeeding effect, disruption of attachment, expellency and/ or killing effect), so it is important to use suitable acaricides to kill the ticks as quickly as possible before pathogens are released. Considering babesiosis, it is even better to prevent ticks from attaching (tick repellency sensu stricto) [137].

A broad spectrum of acaricidal products are licensed for use in dogs all over Europe. The different presentations include long-lasting efficacy collars (6-8 months), spot-on pipettes (3-5 weeks), sprays (2-3 days) and the new oral chewable tablets (1-3 months). These new oral molecules are systemic acaricides; thus, ticks have to attach to the host and start to feed to encounter the active ingredients. 
In addition, reports are still rare regarding the efficacy of acaricidal products to prevent Babesia infection. These studies are mainly confined to $B$. canis transmission by $D$. reticulatus in dogs with percentages of protection that range between 88 and $100 \%$ with a duration from 4 weeks to 3 months (Table 5).

According to the registration of these compounds in Europe, all of them can kill the already feeding tick before the estimated $48 \mathrm{~h}$ of sporogony of Babesia spp. in ticks [138], necessary for its transmission to dogs, which starts when the tick begins to feed. Of note, dogs exposed experimentally to $D$. reticulatus containing $B$. canis tested positive for Babesia (PCR, blood smears) after a 72-h infestation [139].

Different reports have documented the efficacy and speed of killing ticks under natural infestations or after exposure to experimental infestations when dogs are treated with the different ectoparasiticides available. In general, they are all useful, and the veterinarian should tailor the best choice considering each individual dog (lifestyle, outdoor activities, working dogs, human-animal bond).

ESCCAP (European Scientific Counsel Companion Animal Parasites) have therapy tables in each country with the whole portfolio available in Europe (www.esccap.org).

\section{Are there vaccines available to prevent babesiosis in dogs?} A few commercially available vaccine options exist to prevent Babesia infection in different animal species. For the European market, a vaccine to protect $\operatorname{dogs}$ against $B$. canis is available, called Pirodog (Merial). This vaccine, which comprises soluble parasite antigens obtained from culture media supernatant [140-144], induces a partial protection for dogs newly exposed to $B$. canis, which both shortens and diminishes the severity of their clinical signs. Vaccination does not prevent infection but appears to block initiation of many of the pathological processes involved in the disease; moreover, a lower parasitemia may result. This vaccine can be administered from 5 months of age and requires annual re-vaccination but does not cross-protect against other Babesia species. Vaccines against other Babesia species such as B. gibsoni are currently being developed $[145,146]$.

\section{Are there other options available to prevent canine babesiosis?}

Although it is fair to say that the best way to control babesiosis is to counter the vector itself, alternatives other than vaccine development have been studied. One possibility is a chemoprophylactic approach with a few dated reports showing the effectiveness of the carbanilide derivative imidocarb dipropionate against $B$. canis infection. In one instance, $6 \mathrm{mg} / \mathrm{kg}$ administered in three doses, each separated by one week, resulted in no improvement [105]. However, a second study using a single subcutaneous dose (again, $6 \mathrm{mg} / \mathrm{kg}$ ) demonstrated protection for two weeks [147]. Doxycycline, used at a dose of $5 \mathrm{mg} / \mathrm{kg} /$ day, reduces the severity of disease in dogs infected experimentally with an extremely pathogenic isolate of B. canis [117]. However, the chemoprophylactic use of these drugs should be restricted to immunosuppressed dogs (primarily splenectomised dogs) with an increased risk of exposure, including their residence in endemic areas. For these patients, strict clinical and parasitological follow-ups are needed using serological diagnoses and supported with daily blood smears for at least two weeks post-surgery [10]. The demonstration of Babesia spp. transmission after blood transfusion, even when using donor dogs that appear to be clinically healthy [43], reinforces the need to test all prospective canine blood donors with serology and PCR assays before transfusion [148]. Dogs positive by either or both methods should not be used for blood donation.

\section{Conclusions}

Information on canine babesiosis in Europe has significantly increased in the last few years. The present

Table 5 Acaricides with proven preventive efficacy against Babesia spp. transmission by D. reticulatus and R. sanguineus ticks in dogs

\begin{tabular}{|c|c|c|c|}
\hline Principle active (Brand name, presentation - company) & $\begin{array}{l}\text { Percentage of protection of } B \text {. canis } \\
\text { infection (time period of evaluation) }\end{array}$ & $\begin{array}{l}\text { Acaricide efficacy against D. reticulatus } \\
\text { in } \% \text { (time period of evaluation) }\end{array}$ & Reference \\
\hline Afoxolaner (NexGard ${ }^{\oplus}$, chewable tablets - MERIAL) & 100 (56 days) & 99 (4 weeks) & [173] \\
\hline $\begin{array}{l}\text { Fipronil + Permethrin (Frontline Tri-Act }{ }^{\oplus} \text {, Spot } \\
\text { on - MERIAL) }\end{array}$ & 94.3 (4 weeks) & 98.3 (28 days) & [174] \\
\hline Fluralaner (Bravecto ${ }^{\oplus}$, chewable tablets - MSD) & 100 (12 weeks) & 99.2 (86 days) & [175] \\
\hline \multirow[t]{2}{*}{ Flumethrin + Imidacloprid (Seresto ${ }^{\circledR}$ Collar - BAYER) } & 100 (4 weeks) & 96.0 (48 h), 100 (4 days) & [176] \\
\hline & $\begin{array}{l}\text { Percentage of protection of } B \text {. vogeli } \\
\text { infection (time period of evaluation) }\end{array}$ & $\begin{array}{l}\text { Acaricide efficacy against } R \text {. sanguineus } \\
\text { in \% (time period of evaluation) }\end{array}$ & \\
\hline Flumethrin + Imidacloprid (Seresto ${ }^{\oplus}$ Collar - BAYER) & 100 (1 year) & 99.7 (48 h) & [177] \\
\hline Imidacloprid + Permethrin (Advantix ${ }^{\oplus}$, spot on - BAYER) & 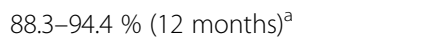 & 95-100 & {$[178,179]$} \\
\hline
\end{tabular}

aThe molecular diagnosis was Babesia spp. Identification to the species level was not carried out. However, the studies were performed in the south of Italy, so that the species of Babesia infecting dogs was most likely B. vogeli 
guidelines aim to answer common questions about the aetiology, epidemiology and transmission routes, clinical signs, laboratory findings, diagnosis, treatment and prophylaxis of infections caused by Babesia spp. We also hope that this review will contribute to the understanding of the current status of these diseases in Europe. It is important to highlight that canine babesiosis represents a group of diseases and that many species can infect dogs in Europe. Therefore, accurate detection and species recognition is crucial for selecting the most appropriate treatment and determining the most accurate prognosis.

\begin{abstract}
Abbreviations
ALP, Alkaline phosphatase; ALT, Alanine aminotransferase; AST, Aspartate transaminase; ELISA, enzyme-linked immunosorbent assay; ENTRA group, abbreviation in Spanish for Grupo de Estudio de Enfermedades Transmitidas por Artrópodos (Arthropod-Borne Disease Experts Group); EDTA, Ethylenediaminetetraacetic acid; ESCCAP, European Scientific Counsel of Companion Animal Parasites; IFAT, immunofluorescence antibody test; IM, intramuscular; IMHA, immune mediated haemolytic anemia; ITS, internal transcribed spacer; $\mathrm{IV}$, intravenous; $\mathrm{PCR}$, polymerase chain reaction; PD, polydipsia; $\mathrm{PO}$, per os (oral administration); PU, polyuria; SC, subcutaneous; SID, drug given once a day; TID, drug given twice a day
\end{abstract}

\section{Acknowledgements}

The authors would like to acknowledge Merial Laboratorios (Spain), the sponsor of this manuscript, with a special mention to Dr. Marta León for providing valuable assistance. The authors are also grateful to the reviewers of this manuscript and the Editor-in-Chief of Parasites \& Vectors.

\section{Funding}

Publication fees of this manuscript have been sponsored by Merial Laboratorios (Spain).

\section{Availability of data and material}

Not applicable.

\section{Authors' contributions}

LSG, AS, XR, GM, and AEP designed the initial structure of the guideline and wrote the first version of the manuscript. LSG participated as the coordinator of this manuscript. All authors read and approved the final manuscript.

\section{Authors' information}

The ENTRA group (abbreviation in Spanish for Grupo de Estudio de Enfermedades Transmitidas por Artrópodos - Arthropod-Borne Disease Experts Group) is composed of Spanish veterinary scientists whose careers have focused on the research of arthropods and arthropod-borne diseases. The main goal of this group is to process and report the most significant information on these diseases. This work is deemed useful for small animal veterinary practitioners. On that basis, the ENTRA group decided to publish practical guidelines regarding babesiosis in dogs, given the recent advances in the study of babesiosis and the high prevalence rates described in Europe. These guidelines are the result of an exhaustive review of the literature in addition to the practical experience of the authors, and their consensus opinions are provided. The questions posed throughout this document are intended to address the most common concerns about these diseases, and the answers provided are from a practical viewpoint.

\section{Competing interests}

The five authors of this review manuscript (AS, XR, GM, AEP, and LSG) are members of the scientific independent group ENTRA, which is supported by Merial Laboratorios (Spain).

\section{Consent for publication}

Not applicable.
Ethics approval and consent to participation

Not applicable.

\section{Author details}

${ }^{1}$ Department of Animal Medicine and Surgery, Faculty of Veterinary Medicine, Universitat Autònoma de Barcelona, Barcelona, Spain. ²Department of Animal Medicine and Surgery, Veterinary Clinic Hospital, Faculty of Veterinary Medicine, Universidad Complutense de Madrid, Madrid, Spain. ${ }^{3}$ Hospital Clínic Veterinari, Universitat Autònoma de Barcelona, Barcelona, Spain. ${ }^{4}$ Department of Animal Pathology, Faculty of Veterinary Medicine, University of Zaragoza, Zaragoza, Spain. ${ }^{5}$ Department of Animal Health, Veterinary Clinic Hospital, Faculty of Veterinary Medicine, Universidad Complutense de Madrid, Madrid, Spain.

Received: 4 December 2015 Accepted: 17 May 2016

Published online: 11 June 2016

\section{References}

1. Uilenberg G. Babesia-a historical overview. Vet Parasitol. 2006;138:3-10.

2. Roncalli AR. The history of Italian parasitology. Vet Parasitol. 2001;98:3-30.

3. Boozer AL, Macintire DK. Canine babesiosis. Vet Clin North Am Small Anim Pract. 2003:33:885-904.

4. Solano-Gallego L, Baneth G. Babesiosis in dogs and cats - expanding parasitological and clinical spectra. Vet Parasitol. 2011;181:48-60.

5. Schnittger $L$, Rodriguez AE, Florin-Christensen M, Morrison DA. Babesia: a world emerging. Infect Genet Evol. 2012;12:1788-809.

6. Carret C, Delbecq S, Labesse G, Carcy B, Precigout E, et al. Characterization and molecular cloning of an adenosine kinase from Babesia canis rossi. Eur J Biochem. 1999;265:1015-21.

7. Zahler M, Schein E, Rinder H, Gothe R. Characteristic genotypes discriminate between Babesia canis isolates of differing vector specificity and pathogenicity to dogs. Parasitol Res. 1998;84:544-8.

8. Carret C, Walas F, Carcy B, Grande N, Precigout E, et al. Babesia canis canis, Babesia canis vogeli, Babesia canis rossi: differentiation of the three subspecies by a restriction fragment length polymorphism analysis on amplified small subunit ribosomal RNA genes. J Eukaryot Microbiol. 1999;46:298-303.

9. Caccio SM, Antunovic B, Moretti A, Mangili V, Marinculic A, et al. Molecular characterisation of Babesia canis canis and Babesia canis vogeli from naturally infected European dogs. Vet Parasitol. 2002;106:285-92.

10. Irwin PJ. Canine babesiosis: from molecular taxonomy to control. Parasit Vectors. 2009:2 Suppl 1:S4.

11. Birkenheuer AJ, Neel J, Ruslander D, Levy MG, Breitschwerdt EB. Detection and molecular characterization of a novel large Babesia species in a dog. Vet Parasitol. 2004;124:151-60.

12. Kjemtrup AM, Conrad PA. A review of the small canine piroplasms from California: Babesia conradae in the literature. Vet Parasitol. 2006:138:112-7.

13. Kjemtrup AM, Wainwright K, Miller M, Penzhorn BL, Carreno RA. Babesia conradae, sp. nov., a small canine Babesia identified in California. Vet Parasitol. 2006;138:103-11.

14. Baneth G, Florin-Christensen M, Cardoso L, Schnittger L. Reclassification of Theileria annae as Babesia vulpes sp. nov. Parasit Vectors. 2015;8:207.

15. Zahler M, Rinder $H$, Schein $E$, Gothe R. Detection of a new pathogenic Babesia microti-like species in dogs. Vet Parasitol. 2000;89:241-8.

16. Camacho-Garcia AT. Piroplasma infection in dogs in northern Spain. Vet Parasitol. 2006:138:97-102.

17. Rosa CT, Pazzi P, Nagel S, McClure V, Christie J, Troskie M, Dvir E. Theileriosis in six dogs in South Africa and its potential clinical significance. J S Afr Vet Assoc. 2014;85:1114.

18. Matjila PT, Leisewitz AL, Oosthuizen MC, Jongejan F, Penzhorn BL. Detection of a Theileria species in dogs in South Africa. Vet Parasitol. 2008;157:34-40.

19. Fritz D. A PCR study of piroplasms in 166 dogs and 111 horses in France (March 2006 to March 2008). Parasitol Res. 2010;106:1339-42.

20. Criado-Fornelio A, Rey-Valeiron C, Buling A, Barba-Carretero JC, Jefferies R, et al. New advances in molecular epizootiology of canine hematic protozoa from Venezuela. Thailand and Spain Vet Parasitol. 2007;144:261-9.

21. Beck R, Vojta L, Mrljak V, Marinculic A, Beck A, et al. Diversity of Babesia and Theileria species in symptomatic and asymptomatic dogs in Croatia. Int J Parasitol. 2009:39:843-8.

22. Qablan MA, Kubelova M, Siroky P, Modry D, Amr ZS. Stray dogs of northern Jordan as reservoirs of ticks and tick-borne hemopathogens. Parasitol Res. 2012;111:301-7. 
23. Adamu M, Troskie M, Oshadu DO, Malatji DP, Penzhorn BL, Matjila PT. Occurrence of tick-transmitted pathogens in dogs in Jos, Plateau State Nigeria. Parasit Vectors. 2014;7:119.

24. Petney TN, Pfaeffle MP, Skuballa JD. An annotated checklist of the ticks (Acari: Ixodida) of Germany. System Appl Acarol. 2012;17:115-70.

25. Mierzejewska EJ, Estrada-Pena A, Alsarraf M, Kowalec M, Bajer A. Mapping of Dermacentor reticulatus expansion in Poland in 2012-2014. Ticks Tick Borne Dis. 2016;7:94-106.

26. Mehlhorn H, Schein E, Voigt WP. Light and electron microscopic study on developmental stages of Babesia canis within the gut of the tick Dermacentor reticulatus. J Parasitol. 1980;66:220-8.

27. Martinod S, Brossard M, Moreau Y. Immunity of dogs against Babesia canis, its vector tick Dermacentor reticulatus, and Ixodes ricinus in endemic area. J Parasitol. 1985;71:269-73.

28. Uilenberg G, Franssen FF, Perie NM, Spanjer AA. Three groups of Babesia canis distinguished and a proposal for nomenclature. Vet $Q$. 1989;11:33-40.

29. Rubel F, Brugger K, Monazahian M, Habedank B, Dautel H, et al. The first German map of georeferenced ixodid tick locations. Parasit Vectors. 2014;7:477.

30. Hansford KM, Pietzsch ME, Cull B, Medlock JM. Importation of $R$. sanquineus into the UK via dogs: tickborne diseases. Vet Rec. 2014;175(15):385-6.

31. Nava S, Estrada-Pena A, Petney T, Beati L, Labruna MB, et al. The taxonomic status of Rhipicephalus sanguineus (Latreille, 1806). Vet Parasitol. 2015;208:2-8.

32. Gray J, Dantas-Torres F, Estrada-Pena A, Levin M. Systematics and ecology of the brown dog tick. Rhipicephalus sanguineus. Ticks Tick Borne Dis. 2013:4:171-80.

33. Iwakami S, Ichikawa Y, Inokuma H. Molecular survey of Babesia gibsoni using Haemaphysalis longicornis collected from dogs and cats in Japan. J Vet Med Sci. 2014;76:1313-6.

34. Hatta T, Matsubayashi M, Miyoshi T, Islam K, Alim MA, et al. Quantitative PCR-based parasite burden estimation of Babesia gibsoni in the vector tick Haemaphysalis longicornis (Acari: Ixodidae), fed on an experimentally infected dog. J Vet Med Sci. 2013;75:1-6.

35. Miro G, Checa R, Paparini A, Ortega N, Gonzalez-Fraga JL, et al. Theileria annae (syn. Babesia microti-like) infection in dogs in NW Spain detected using direct and indirect diagnostic techniques: clinical report of 75 cases. Parasit Vectors. 2015;8:217.

36. Camacho AT, Pallas E, Gestal JJ, Guitian FJ, Olmeda AS, et al. Ixodes hexagonus is the main candidate as vector of Theileria annae in northwest Spain. Vet Parasitol. 2003;1 12:157-63.

37. Gilot B, Pautou G, Immler R, Moncada E. Suburban biotype of Dermacentor reticulatus (Fabricius, 1794) (Ixodoidea). Preliminary study. Rev Suisse Zool. 1973;80:411-30.

38. Gilot B, Robin Y, Pautou G, Moncada E, Vigny MF. Écologie et rôle pathogène de Dermacentor reticulatus (Fabricius, 1794) (Ixodoidea) dans le sud-est de la France. Acarol. 1974;16:220-49.

39. Harris SY, Thompson GB. Populations of the ticks Ixodes (Pholeoixodes) hexagonus and Ixodes (Pholeoixodes) canisuga infesting suburban foxes Vulpes vulpes. J Zool. 1978;186:83-93.

40. Lledo L, Gimenez-Pardo C, Dominguez-Penafiel G, Sousa R, Gegundez MI, et al. Molecular detection of hemoprotozoa and Rickettsia species in arthropods collected from wild animals in the Burgos Province, Spain. Vector Borne Zoonotic Dis. 2010;10:735-8.

41. Najm NA, Meyer-Kayser E, Hoffmann L, Herb I, Fensterer V, et al. A molecular survey of Babesia spp. and Theileria spp. in red foxes (Vulpes vulpes) and their ticks from Thuringia, Germany. Ticks Tick Borne Dis. 2014;5:386-91.

42. Sainz A, Roura X, Miro G, Estrada-Pena A, Kohn B, et al. Guideline for veterinary practitioners on canine ehrlichiosis and anaplasmosis in Europe. Parasit Vectors. 2015:8:75.

43. Stegeman JR, Birkenheuer AJ, Kruger JM, Breitschwerdt EB. Transfusionassociated Babesia gibsoni infection in a dog. J Am Vet Med Assoc. 2003; 222:959-63.

44. Fukumoto S, Suzuki H, Igarashi I, Xuan X. Fatal experimental transplacental Babesia gibsoni infections in dogs. Int J Parasitol. 2005:35:1031-5.

45. Birkenheuer AJ, Correa MT, Levy MG, Breitschwerdt EB. Geographic distribution of babesiosis among dogs in the United States and association with dog bites: 150 cases (2000-2003). J Am Vet Med Assoc. 2005;227:942-7.
46. Jefferies R, Ryan UM, Jardine J, Broughton DK, Robertson ID, Irwin PJ. Blood, bull terriers and babesiosis: further evidence for direct transmission of Babesia gibsoni in dogs. Aust Vet J. 2007;85:459-63.

47. Yeagley TJ, Reichard MV, Hempstead JE, Allen KE, Parsons LM, et al. Detection of Babesia gibsoni and the canine small Babesia 'Spanish isolate' in blood samples obtained from dogs confiscated from dogfighting operations. J Am Vet Med Assoc. 2009;235:535-9.

48. Trotta M, Carli E, Novari G, Furlanello T, Solano-Gallego L. Clinicopathological findings, molecular detection and characterization of Babesia gibsoni infection in a sick dog from Italy. Vet Parasitol. 2009;165:318-22.

49. Mierzejewska EJ, Welc-Faleciak R, Bednarska M, Rodo A, Bajer A. The first evidence for vertical transmission of Babesia canis in a litter of central Asian Shepherd dogs. Ann Agric Environ Med. 2014;21:500-3.

50. Simoes PB, Cardoso L, Araujo M, Yisaschar-Mekuzas Y, Baneth G. Babesiosis due to the canine Babesia microti-like small piroplasm in dogs-first report from Portugal and possible vertical transmission. Parasit Vectors. 2011:4:50.

51. Davitkov D, Vucicevic M, Stevanovic J, Krstic V, Tomanovic S, et al. Clinical babesiosis and molecular identification of Babesia canis and Babesia gibsoni infections in dogs from Serbia. Acta Vet Hung. 2015;63:199-208.

52. Karbowiak G. The occurrence of the Dermacentor reticulatus tick-its expansion to new areas and possible causes. Ann Parasitol. 2014;60:37-47.

53. Halos L, Lebert I, Chao I, Vourc'h G, Ducrot C, et al. Questionnaire-based survey on distribution and clinical incidence of canine babesiosis in France. BMC Vet Res. 2013:9:41.

54. Carcy B, Randazzo S, Depoix D, Adaszek L, Cardoso L, et al. Classification of Babesia canis strains in Europe based on polymorphism of the Bc28.1-gene from the Babesia canis Bc28 multigene family. Vet Parasitol. 2015;211:111-23.

55. Ionita M, Mitrea IL, Pfister K, Hamel D, Buzatu CM, Silaghi C. Canine babesiosis in Romania due to Babesia canis and Babesia vogeli: a molecular approach. Parasitol Res. 2012;110:1659-64

56. Rene M, Chene J, Beaufils JP, Valiente Moro C, Bourdoiseau G, et al. First evidence and molecular characterization of Babesia vogeli in naturally infected dogs and Rhipicephalus sanguineus ticks in southern France. Vet Parasitol. 2012;187:399-407.

57. Cassini R, Zanutto S, Frangipane di Regalbono A, Gabrielli S, Calderini P, et al. Canine piroplasmosis in Italy: epidemiological aspects in vertebrate and invertebrate hosts. Vet Parasitol. 2009;165:30-5.

58. Duh D, Tozon N, Petrovec M, Strasek K, Avsic-Zupanc T. Canine babesiosis in Slovenia: molecular evidence of Babesia canis canis and Babesia canis vogeli. Vet Res. 2004;35:363-8.

59. Welc-Faleciak R, Rodo A, Sinski E, Bajer A. Babesia canis and other tick-borne infections in dogs in Central Poland. Vet Parasitol. 2009;166:191-8.

60. Hamel D, Silaghi C, Lescai D, Pfister K. Epidemiological aspects on vectorborne infections in stray and pet dogs from Romania and Hungary with focus on Babesia spp. Parasitol Res. 2012;110:1537-45.

61. Criado-Fornelio A, Buling A, Pingret JL, Etievant M, Boucraut-Baralon C, et al. Hemoprotozoa of domestic animals in France: Prevalence and molecular characterization. Vet Parasitol. 2009;159:73-6.

62. Gabrielli S, Otasevic S, Ignjatovic A, Savic S, Fraulo M, et al. Canine babesioses in noninvestigated areas of Serbia. Vector Borne Zoonotic Dis. 2015;15:535-8.

63. Falkeno U, Tasker S, Osterman-Lind E, Tvedten HW. Theileria annae in a young Swedish dog. Acta Vet Scand. 2013;55:50.

64. Rene-Martellet M, Moro CV, Chene J, Bourdoiseau G, Chabanne L, Mavingui P. Update on epidemiology of canine babesiosis in Southern France. BMC Vet Res. 2015;11:223.

65. Camacho AT, Pallas E, Gestal JJ, Guitian FJ, Olmeda AS, et al. Infection of dogs in north-west Spain with a Babesia microti-like agent. Vet Rec. 2001;149:552-5.

66. Criado-Fornelio A, Martinez-Marcos A, Buling-Sarana A, Barba-Carretero JC. Molecular studies on Babesia, Theileria and Hepatozoon in southern Europe. Part I. Epizootiological aspects. Vet Parasitol. 2003;113:189-201.

67. Cardoso L, Cortes HC, Reis A, Rodrigues P, Simoes M, et al. Prevalence of Babesia microti-like infection in red foxes (Vulpes vulpes) from Portugal. Vet Parasitol. 2013:196:90-5.

68. Zanet S, Trisciuoglio A, Bottero E, de Mera IG, Gortazar C, et al. Piroplasmosis in wildlife: Babesia and Theileria affecting free-ranging ungulates and carnivores in the Italian Alps. Parasit Vectors. 2014;7:70.

69. Dezdek D, Vojta L, Curkovic S, Lipej Z, Mihaljevic Z, et al. Molecular detection of Theileria annae and Hepatozoon canis in foxes (Vulpes vulpes) in Croatia. Vet Parasitol. 2010:172:333-6. 
70. Duscher GG, Fuehrer HP, Kubber-Heiss A. Fox on the run - molecular surveillance of fox blood and tissue for the occurrence of tick-borne pathogens in Austria. Parasit Vectors. 2014;7:521.

71. Farkas R, Takacs N, Hornyak A, Nachum-Biala Y, Hornok S, Baneth G. First report on Babesia cf. microti infection of red foxes (Vulpes vulpes) from Hungary. Parasit Vectors. 2015;8:55

72. Hodzic A, Alic A, Fuehrer HP, Harl J, Wille-Piazzai W, Duscher GG. A molecular survey of vector-borne pathogens in red foxes (Vulpes vulpes) from Bosnia and Herzegovina. Parasit Vectors. 2015;8:88.

73. Hartelt K, Rieker T, Oehme RM, Brockmann SO, Muller W, Dorn N. First evidence of Babesia gibsoni (Asian genotype) in dogs in Western Europe. Vector Borne Zoonotic Dis. 2007;7:163-6.

74. Criado-Fornelio A, Gonzalez-del-Rio MA, Buling-Sarana A, Barba-Carretero JC. Molecular characterization of a Babesia gibsoni isolate from a Spanish dog. Vet Parasitol. 2003;117:123-9.

75. Tabar MD, Francino O, Altet L, Sanchez A, Ferrer L, Roura X. PCR survey of vectorborne pathogens in dogs living in and around Barcelona, an area endemic for leishmaniosis. Vet Rec. 2009;164:112-6.

76. Homer MJ, Aguilar-Delfin I, Telford SR, Krause PJ, Persing DH. Babesiosis. Clin Microbiol Rev. 2000;13:451-69.

77. Kjemtrup AM, Conrad PA. Human babesiosis: an emerging tick-borne disease Int J Parasitol. 2000;30:1323-37.

78. Yabsley MJ, Shock BC. Natural history of Zoonotic Babesia: Role of wildlife reservoirs. Intern J Parasitol Parasit Wild. 2013;2:18-31.

79. Hornok S, Edelhofer R, Farkas R. Seroprevalence of canine babesiosis in Hungary suggesting breed predisposition. Parasitol Res. 2006;99:638-42.

80. Martinod S, Laurent N, Moreau Y. Resistance and immunity of dogs against Babesia canis in an endemic area. Vet Parasitol. 1986;19:245-54.

81. Taboada J, Harvey JW, Levy MG, Breitschwerdt EB. Seroprevalence of babesiosis in Greyhounds in Florida. J Am Vet Med Assoc. 1992;200:47-50

82. Mellanby RJ, Handel IG, Clements DN, Bronsvoort BM, Lengeling A, Schoeman JP. Breed and sex risk factors for canine babesiosis in South Africa. J Vet Intern Med. 2011;25:1186-9.

83. Hughes VL, Randolph SE. Testosterone increases the transmission potential of tick-borne parasites. Parasitol. 2001;123:365-71.

84. Solano-Gallego L, Trotta M, Carli E, Carcy B, Caldin M, Furlanello T. Babesia canis canis and Babesia canis vogeli clinicopathological findings and DNA detection by means of PCR-RFLP in blood from Italian dogs suspected of tick-borne disease. Vet Parasitol. 2008;157:211-21.

85. Keller N, Jacobson LS, Nel M, de Clerq M, Thompson PN, Schoeman JP. Prevalence and risk factors of hypoglycemia in virulent canine babesiosis. J Vet Intern Med. 2004;18:265-70.

86. Camacho AT, Guitian EJ, Pallas E, Gestal JJ, Olmeda AS, et al. Azotemia and mortality among Babesia microti-like infected dogs. J Vet Intern Med. 2004;18:141-6.

87. Kraje AC. Canine haemobartonellosis and babesiosis. Compend Contin Educ. 2001;23:310-8.

88. Bohm M, Leisewitz AL, Thompson PN, Schoeman JP. Capillary and venous Babesia canis rossi parasitaemias and their association with outcome of infection and circulatory compromise. Vet Parasitol. 2006; 141:18-29.

89. Eichenberger RM, Riond B, Willi B, Hofmann-Lehmann R, Deplazes P. Prognostic markers in acute Babesia canis infections. J Vet Intern Med. 2016;30:174-82.

90. Irwin PJ, Hutchinson GW. Clinical and pathological findings of Babesia infection in dogs. Aust Vet J. 1991;68:204-9.

91. Jacobson LS. The South African form of severe and complicated canine babesiosis: clinical advances 1994-2004. Vet Parasitol. 2006;138:126-39.

92. Birkenheuer AJ, Levy MG, Stebbins M, Poore M, Breitschwerdt E. Serosurvey of antiBabesia antibodies in stray dogs and American pit bull terriers and American staffordshire terriers from North Carolina. J Am Anim Hosp Assoc. 2003;39:551-7

93. Solano-Gallego L, Capri A, Pennisi MG, Caldin M, Furlanello T, Trotta M. Acute febrile illness is associated with Rickettsia spp infection in dogs. Parasit Vectors. 2015;8:216.

94. Aboge GO, Jia H, Terkawi MA, Goo Y, Kuriki K, et al. A novel 57-kDa merozoite protein of Babesia gibsoni is a prospective antigen for diagnosis and serosurvey of canine babesiosis by enzyme-linked immunosorbent assay. Vet Parasitol. 2007;149:85-94.
95. Fukumoto $S$, Sekine $Y$, Xuan $X$, Igarashi I, Sugimoto C, et al. Serodiagnosis of canine Babesia gibsoni infection by enzyme-linked immunosorbent assay with recombinant P50 expressed in Escherichia coli. J Parasitol. 2004;90:387-91.

96. Yamane I, Thomford JW, Gardner IA, Dubey JP, Levy M, Conrad PA. Evaluation of the indirect fluorescent antibody test for diagnosis of Babesia gibsoni infections in dogs. Am J Vet Res. 1993;54:1579-84.

97. Kubelova M, Sedlak K, Panev A, Siroky P. Conflicting results of serological, $P C R$ and microscopic methods clarify the various risk levels of canine babesiosis in Slovakia: a complex approach to Babesia canis diagnostics. Vet Parasitol. 2013;191:353-7.

98. Birkenheuer AJ, Levy MG, Breitschwerdt EB. Development and evaluation of a seminested PCR for detection and differentiation of Babesia gibsoni (Asian genotype) and B. canis DNA in canine blood samples. J Clin Microbiol. 2003; 41:4172-7.

99. Matjila PT, Penzhorn BL, Bekker CP, Nijhof AM, Jongejan F. Confirmation of occurrence of Babesia canis vogeli in domestic dogs in South Africa. Vet Parasitol. 2004;122:119-25.

100. Yisaschar-Mekuzas Y, Jaffe CL, Pastor J, Cardoso L, Baneth G. Identification of Babesia species infecting dogs using reverse line blot hybridization for six canine piroplasms, and evaluation of co-infection by other vector-borne pathogens. Vet Parasitol. 2013;191:367-73.

101. Jefferies R, Ryan UM, Irwin PJ. PCR-RFLP for the detection and differentiation of the canine piroplasm species and its use with filter paper-based technologies. Vet Parasitol. 2007;144:20-7.

102. Birkenheuer AJ, Levy MG, Breitschwerdt EB. Efficacy of combined atovaquone and azithromycin for therapy of chronic Babesia gibsoni (Asian genotype) infections in dogs. J Vet Intern Med. 2004;18:494-8.

103. Matjila PT, Leisewitz AL, Jongejan F, Penzhorn BL. Molecular detection of tick-borne protozoal and ehrlichial infections in domestic dogs in South Africa. Vet Parasitol. 2008;155:152-7.

104. Miro G, Montoya A, Roura X, Galvez R, Sainz A. Seropositivity rates for agents of canine vector-borne diseases in Spain: a multicentre study. Parasit Vectors. 2013;6:117.

105. Uilenberg G, Verdiesen PA, Zwart D. Imidocarb: a chemoprophylactic experiment with Babesia canis. Vet Q. 1981;3:118-23.

106. Vial HJ, Gorenflot A. Chemotherapy against babesiosis. Vet Parasitol. 2006; 138:147-60.

107. Sikorski LE, Birkenheuer AJ, Holowaychuk MK, McCleary-Wheeler AL, Davis JM, Littman MP. Babesiosis caused by a large Babesia species in 7 immunocompromised dogs. J Vet Intern Med. 2010;24:127-31.

108. Di Cicco MF, Downey ME, Beeler E, Marr H, Cyrog P, et al. Re-emergence of Babesia conradae and effective treatment of infected dogs with atovaquone and azithromycin. Vet Parasitol. 2012;187:23-7.

109. Krause PJ, Lepore T, Sikand VK, Gadbaw Jr J, Burke G, et al. Atovaquone and azithromycin for the treatment of babesiosis. N Engl J Med. 2000;343:1454-8.

110. Matsuu A, Koshida Y, Kawahara M, Inoue K, Ikadai H, et al. Efficacy of atovaquone against Babesia gibsoni in vivo and in vitro. Vet Parasitol. 2004;124:9-18.

111. Jefferies R, Ryan UM, Jardine J, Robertson ID, Irwin PJ. Babesia gibsoni: detection during experimental infections and after combined atovaquone and azithromycin therapy. Exp Parasitol. 2007;117:115-23.

112. Sakuma M, Setoguchi A, Endo Y. Possible emergence of drug-resistant variants of Babesia gibsoni in clinical cases treated with atovaquone and azithromycin. J Vet Intern Med. 2009;23:493-8.

113. Checa Herraiz R, Ortega Olmedo N, Montoya Matute A, Gálvez Esteban R, González JL, et al. Evaluación de la eficacia terapeútica de dipropionato de imidocarb, atovacuona y buparvacuona en perros con infección natural por Theileria annae: resultados preliminares. In: XXXII Congreso anual AMVAC. Madrid; 2015.

114. Jacobson LS, Reyers F, Berry WL, Viljoen E. Changes in haematocrit after treatment of uncomplicated canine babesiosis: a comparison between diminazene and trypan blue, and an evaluation of the influence of parasitaemia. J S Afr Vet Assoc. 1996;67:77-82.

115. Miller DM, Swan GE, Lobetti RG, Jacobson LS. The pharmacokinetics of diminazene aceturate after intramuscular administration in healthy dogs. J S Afr Vet Assoc. 2005;76:146-50.

116. Lin EC, Chueh LL, Lin CN, Hsieh LE, Su BL. The therapeutic efficacy of two antibabesial strategies against Babesia gibsoni. Vet Parasitol. 2012;186:159-64.

117. Vercammen F, De Deken R, Maes L. Prophylactic treatment of experimental canine babesiosis (Babesia canis) with doxycycline. Vet Parasitol. 1996;66:251-5. 
118. Lin MY, Huang HP. Use of a doxycycline-enrofloxacin-metronidazole combination with/without diminazene diaceturate to treat naturally occurring canine babesiosis caused by Babesia gibsoni. Acta Vet Scand. 2010;52:27.

119. Wulansari R, Wijaya A, Ano H, Horii Y, Nasu T, et al. Clindamycin in the treatment of Babesia gibsoni infections in dogs. J Am Anim Hosp Assoc. 2003;39:558-62.

120. Suzuki K, Wakabayashi H, Takahashi M, Fukushima K, Yabuki A, Endo Y. A Possible treatment strategy and clinical factors to estimate the treatment response in Babesia gibsoni infection. J Vet Med Sci. 2007;69:563-8.

121. Farwell GE, LeGrand EK, Cobb CC. Clinical observations on Babesia gibsoni and Babesia canis infections in dogs. J Am Vet Med Assoc. 1982;180:507-11.

122. Subeki, Nomura S, Matsuura H, Yamasaki M, Yamato O, et al. Anti-babesial activity of some central kalimantan plant extracts and active oligostilbenoids from Shorea balangeran. Planta Med. 2005;71:420-3.

123. Subeki, Matsuura H, Yamasaki M, Yamato O, Maede $Y$, et al. Effects of central Kalimantan plant extracts on intraerythrocytic Babesia gibsoni in culture. J Vet Med Sci. 2004;66:871-4

124. Tsuji N, Battsetseg B, Boldbaatar D, Miyoshi T, Xuan X, et al. Babesial vector tick defensin against Babesia sp. parasites. Infect Immun. 2007;75:3633-40.

125. Goo YK, Terkawi MA, Jia H, Aboge GO, Ooka H, et al. Artesunate, a potential drug for treatment of Babesia infection. Parasitol Int. 2010;59:481-6.

126. Ayoob AL, Hackner SG, Prittie J. Clinical management of canine babesiosis. J Vet Emerg Crit Care (San Antonio). 2010;20:77-89.

127. Grundy SA, Barton C. Influence of drug treatment on survival of dogs with immune-mediated hemolytic anemia: 88 cases (1989-1999). J Am Vet Med Assoc. 2001;218:543-6.

128. Scott-Moncrieff JC, Treadwell NG, McCullough SM, Brooks MB. Hemostatic abnormalities in dogs with primary immune-mediated hemolytic anemia. J Am Anim Hosp Assoc. 2001;37:220-7.

129. Kidd L, Mackman N. Prothrombotic mechanisms and anticoagulant therapy in dogs with immune-mediated hemolytic anemia. J Vet Emerg Crit Care (San Antonio). 2013;23:3-13.

130. Slade DJ, Lees GE, Berridge BR, Clubb FJ, Kuczynski LA, Littman MP. Resolution of a proteinuric nephropathy associated with Babesia gibsoni infection in a dog. J Am Anim Hosp Assoc. 2011;47:e138-44.

131. Bourdoiseau G. Canine babesiosis in France. Vet Parasitol. 2006;138:118-25.

132. Birkenheuer AJ, Levy MG, Savary KC, Gager RB, Breitschwerdt EB. Babesia gibsoni infections in dogs from North Carolina. J Am Anim Hosp Assoc. 1999:35:125-8.

133. Brandao LP, Hagiwara MK, Myiashiro SI. Humoral immunity and reinfection resistance in dogs experimentally inoculated with Babesia canis and either treated or untreated with imidocarb dipropionate. Vet Parasitol. 2003;114: 253-65.

134. Conrad P, Thomford J, Yamane I, Whiting J, Bosma L, et al. Hemolytic anemia caused by Babesia gibsoni infection in dogs. J Am Vet Med Assoc. 1991;199:601-5

135. Jongejan F, Ringenier M, Putting M, Berger L, Burgers $S$, et al. Novel foci of Dermacentor reticulatus ticks infected with Babesia canis and Babesia caballi in the Netherlands and in Belgium. Parasit Vectors. 2015;8:232.

136. Duscher GG, Feiler A, Leschnik M, Joachim A. Seasonal and spatial distribution of ixodid tick species feeding on naturally infested dogs from Eastern Austria and the influence of acaricides/repellents on these parameters. Parasit Vectors. 2013;6:76

137. Halos L, Baneth G, Beugnet F, Bowman AS, Chomel B, et al. Defining the concept of 'tick repellency' in veterinary medicine. Parasitol. 2012;139:419-23.

138. Schein E, Mehlhorn H, Voigt WP. Electron microscopical studies on the development of Babesia canis (Sporozoa) in the salivary glands of the vector tick Dermacentor reticulatus. Acta Trop. 1979:36:229-41.

139. Heile C, Schein E. Kürzeste Übertragungszeiten von Babesia canis canis durch Dermacentor reticulatus. Vet-Med Report. 2007:31:2

140. Moreau Y, Vidor E, Bissuel G, Dubreuil N. Vaccination against canine babesiosis: an overview of field observations. Trans R Soc Trop Med Hyg. 1989;83(Suppl):95-6.

141. Schetters TP, Moubri K, Cooke BM. Comparison of Babesia rossi and Babesia canis isolates with emphasis on effects of vaccination with soluble parasite antigens: a review. J S Afr Vet Assoc. 2009;80:75-8.

142. Schetters T. Vaccination against canine babesiosis. Trends Parasitol. 2005; 21:179-84.
143. Schetters TP, Kleuskens JA, Scholtes NC, Pasman JW, Bos HJ. Vaccination of dogs against Babesia canis infection using antigens from culture supernatants with emphasis on clinical babesiosis. Vet Parasitol. 1994;52:219-33.

144. Schetters TP, Kleuskens JA, Scholtes NC, Pasman JW, Goovaerts D. Vaccination of dogs against Babesia canis infection. Vet Parasitol. 1997;73:35-41.

145. Fukumoto S, Tamaki $Y$, Igarashi I, Suzuki H, Xuan X. Immunogenicity and growth inhibitory efficacy of the prime-boost immunization regime with DNA followed by recombinant vaccinia virus carrying the P29 gene of Babesia gibsoni in dogs. Exp Parasitol. 2009;123:296-301.

146. Fukumoto S, Tamaki Y, Okamura M, Bannai H, Yokoyama N, et al. Primeboost immunization with DNA followed by a recombinant vaccinia virus expressing P50 induced protective immunity against Babesia gibsoni infection in dogs. Vaccine. 2007;25:1334-41.

147. Vercammen F, De Deken R, Maes L. Prophylactic activity of imidocarb against experimental infection with Babesia canis. Vet Parasitol. 1996;63:195-8.

148. Crawford K, Walton J, Lewis D, Tasker S, Warman SM. Infectious agent screening in canine blood donors in the United Kingdom. J Small Anim Pract. 2013;54:414-7.

149. Otranto D, Testini G, Dantas-Torres F, Latrofa MS, Paulo P, et al. Diagnosis of canine vector-borne diseases in young dogs: a longitudinal study. J Clin Microbiol. 2010:48:3316-24.

150. Cardoso L, Costa A, Tuna J, Vieira L, Eyal O, et al. Babesia canis canis and Babesia canis vogeli infections in dogs from northern Portugal. Vet Parasitol. 2008;156:199-204

151. Gulanber A, Gorenflot A, Schetters TP, Carcy B. First molecular diagnosis of Babesia vogeli in domestic dogs from Turkey. Vet Parasitol. 2006;139:224-30.

152. Vichova B, Horska M, Blanarova L, Svihran M, Andersson M, Petko B. First molecular identification of Babesia gibsoni in dogs from Slovakia, central Europe. Ticks Tick Borne Dis. 2016;7:54-9.

153. Imre M, Farkas R, llie MS, Imre K, Darabus G. Survey of babesiosis in symptomatic dogs from Romania: occurrence of Babesia gibsoni associated with breed. Ticks Tick Borne Dis. 2013:4:500-2

154. Smith FD, Wall LE. Prevalence of Babesia and Anaplasma in ticks infesting dogs in Great Britain. Vet Parasitol. 2013;198:18-23.

155. Suarez ML, Espino L, Goicoa A, Fidalgo LE, Santamarina G. Fatal Babesia gibsoni infection in a dog from Spain. Vet Rec. 2001;148:819-20.

156. Pennisi MG, Capri A, Solano-Gallego L, Lombardo G, Torina A, Masucci M. Prevalence of antibodies against Rickettsia conorii, Babesia canis, Ehrlichia canis, and Anaplasma phagocytophilum antigens in dogs from the Stretto di Messina area (Italy). Ticks Tick Borne Dis. 2012:3:315-8.

157. Vichova B, Miterpakova M, Iglodyova A. Molecular detection of co-infections with Anaplasma phagocytophilum and/or Babesia canis canis in Dirofilariapositive dogs from Slovakia. Vet Parasitol. 2014;203:167-72.

158. Paulauskas A, Radzijevskaja J, Karveliene B, Grigonis A, Aleksandraviciene A et al. Detection and molecular characterization of canine babesiosis causative agent Babesia canis in the naturally infected dog in Lithuania. Vet Parasitol. 2014;205:702-6.

159. Aktas M, Ozubek S, Altay K, Ipek ND, Balkaya I, et al. Molecular detection of tick-borne rickettsial and protozoan pathogens in domestic dogs from Turkey. Parasit Vectors. 2015;8:157.

160. Pantchev N, Schnyder M, Vrhovec MG, Schaper R, Tsachev I. Current surveys of the seroprevalence of Borrelia burgdorferi, Ehrlichia canis, Anaplasma phagocytophilum, Leishmania infantum, Babesia canis, Angiostrongylus vasorum and Dirofilaria immitis in dogs in Bulgaria. Parasitol Res. 2015;114 Suppl 1:S117-30.

161. Camacho AT, Guitian FJ, Pallas E, Gestal JJ, Olmeda S, et al. Serum protein response and renal failure in canine Babesia annae infection. Vet Res. 2005; 36:713-22.

162. Carli E, Tasca S, Trotta M, Furlanello T, Caldin M, Solano-Gallego L. Detection of erythrocyte binding $\operatorname{lgM}$ and $\lg \mathrm{G}$ by flow cytometry in sick dogs with Babesia canis canis or Babesia canis vogeli infection. Vet Parasitol. 2009;162:51-7.

163. Mathe A, Voros K, Papp L, Reiczigel J. Clinical manifestations of canine babesiosis in Hungary (63 cases). Acta Vet Hung. 2006;54:367-85.

164. Zygner W, Rapacka G, Gojska-Zygner O, Dlugosz E, Wedrychowicz H. Biochemical abnormalities observed in serum of dogs infected with large Babesia in Warsaw (Poland). Pol J Vet Sci. 2007:10:245-53.

165. Furlanello T, Fiorio F, Caldin M, Lubas G, Solano-Gallego L. Clinicopathological findings in naturally occurring cases of babesiosis caused by large form Babesia from dogs of northeastern Italy. Vet Parasitol. 2005:134:77-85. 
166. Zygner W, Gojska-Zygner O, Baska P, Dlugosz E. Low T3 syndrome in canine babesiosis associated with increased serum IL-6 concentration and azotaemia. Vet Parasitol. 2015;211:23-7.

167. Gojska-Zygner O, Zygner W. Hyperaldosteronism and its association with hypotension and azotaemia in canine babesiosis. Vet Q. 2015;35:37-42.

168. Macintire DK, Boudreaux MK, West GD, Bourne C, Wright JC, Conrad PA. Babesia gibsoni infection among dogs in the southeastern United States. J Am Vet Med Assoc. 2002;220:325-9.

169. Meinkoth JH, Kocan AA, Loud SD, Lorenz MD. Clinical and hematologic effects of experimental infection of dogs with recently identified Babesia gibsoni-like isolates from Oklahoma. J Am Vet Med Assoc. 2002; 220:185-9.

170. Lee MJ, Yu DH, Yoon JS, Li YH, Lee JH, et al. Epidemiologic and clinical surveys in dogs infected with Babesia gibsoni in South Korea. Vector Borne Zoonotic Dis. 2009:9:681-6.

171. Gonde S, Chhabra S, Singla LD, Bansal BK. Peritoneal effusion in a dog due to Babesia gibsoni infection. Case Rep Vet Med. 2014;1-4.

172. Guitian FJ, Camacho AT, Telford 3rd SR. Case-control study of canine infection by a newly recognised Babesia microti-like piroplasm. Prev Vet Med. 2003;61:137-45.

173. Beugnet F, Halos L, Larsen D, Labuschagne M, Erasmus H, Fourie J. The ability of an oral formulation of afoxolaner to block the transmission of Babesia canis by Dermacentor reticulatus ticks to dogs. Parasit Vectors. 2014;7:283.

174. Jongejan F, de Vos C, Fourie JJ, Beugnet F. A novel combination of fipronil and permethrin (Frontline Tri-Act(R)/Frontect(R)) reduces risk of transmission of Babesia canis by Dermacentor reticulatus and of Ehrlichia canis by Rhipicephalus sanquineus ticks to dogs. Parasit Vectors. 2015;8:602.

175. Taenzler J, Liebenberg J, Roepke RK, Heckeroth AR. Prevention of transmission of Babesia canis by Dermacentor reticulatus ticks to dogs treated orally with fluralaner chewable tablets (Bravecto). Parasit Vectors. 2015;8:305.

176. Fourie JJ, Stanneck D, Jongejan F. Prevention of transmission of Babesia canis by Dermacentor reticulatus ticks to dogs treated with an imidacloprid/ flumethrin collar. Vet Parasitol. 2013;192:273-8.

177. Dantas-Torres F, Capelli G, Giannelli A, Ramos RA, Lia RP, et al. Efficacy of an imidacloprid/flumethrin collar against fleas, ticks and tick-borne pathogens in dogs. Parasit Vectors. 2013;6:245.

178. Otranto, D, Lia, RP, Cantacessi, C, Galli, G, Paradies, P, Mallia, E et al. Efficacy of a combination of imidacloprid 10\%/permethrin $50 \%$ versus fipronil 10\%/ (S)-methoprene 12\%, against ticks in naturally infected dogs. Vet. Parasitol. 2005:130:293-304.

179. Otranto D, de Caprariis D, Lia RP, Tarallo V, Lorusso V, et al. Prevention of endemic canine vectorborne diseases using imidacloprid $10 \%$ and permethrin $50 \%$ in young dogs: a longitudinal field study. Vet Parasitol. 2010;172:323-32.

\section{Submit your next manuscript to BioMed Central and we will help you at every step:}

- We accept pre-submission inquiries

- Our selector tool helps you to find the most relevant journal

- We provide round the clock customer support

- Convenient online submission

- Thorough peer review

- Inclusion in PubMed and all major indexing services

- Maximum visibility for your research

Submit your manuscript at www.biomedcentral.com/submit

C Biomed Central 